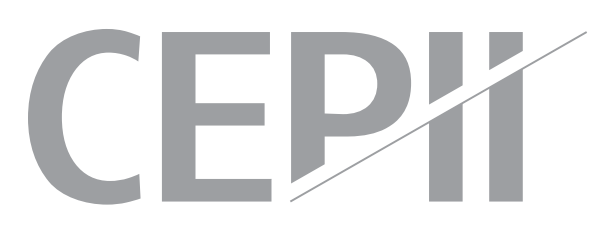

\title{
Trade and Currency Weapons ${ }^{\star}$
}

Agnès Bénassy-Quéré†, Matthieu Bussière $₹$ Pauline Wibaux§

\section{Highlights}

- We estimate the elasticities of exports to tariffs and to the real exchange rate within the same specification, allowing for a direct comparison.

- We find that tariffs have significantly more impact on exports than the real exchange rate, invalidating the symmetry assumption often made in macroeconomic models.

- From the point of view of short-term stabilization, tariffs and monetary policy can be considered as partly substitutes.

- Monetary policy is more stabilizing due to its internal transmission channels; at the zero lower bound, though, there is an incentive to use tariffs for macroeconomic stabilization.

I In normal times, a governement will more likely react to a trade "agression" through monetary rather than through trade retaliation.

\footnotetext{
* We would like to thank Antoine Berthou, Anne-Laure Delatte, Lionel Fontagné, Guillaume Gaulier, Sébastien Jean, Philippe Martin, Thierry Mayer, Ariel Reshef, Walter Steingress Vincent Vicard, Soledad Zignago, and the participants of the $66^{\text {th }}$ AFSE Meetings, $17^{\text {th }}$ RIEF Doctoral Meetings in International Trade and International Finance, $34^{\text {th }}$ Symposium on Money, Banking and Finance, 21 ${ }^{\text {st }}$ Dynamic, Economic Growth and International Trade conference, Banque de France, CEPII and PSE seminars, NBER workshop on Capital Flows, Currency Wars and Monetary Policy, and CESifo Area Conference on the Global Economy, for helpful comments. The views are those of the authors and do not necessarily represent those of the Banque de France or the Eurosystem.

${ }^{\dagger}$ Paris School of Economics, University Paris 1 Panthéon-Sorbonne, France.

‡Banque de France.
}

§Paris School of Economics, University Paris 1 Panthéon-Sorbonne, France, pauline.wibaux@univ-paris1.fr. 


\section{Abstract}

The debate on trade wars and currency wars has re-emerged since the Great recession of 2009. We study the two forms of non-cooperative policies within a single framework. First, we compare the elasticity of trade flows to import tariffs and to the real exchange rate, based on product level data for 110 countries over the 1989-2013 period. We find that a 1 percent depreciation of the importer's currency reduces imports by around 0.5 percent in current dollar, whereas an increase in import tariffs by 1 percentage point reduces imports by around 1.4 percent. Hence the two instruments are not equivalent. Second, we build a stylized short-term macroeconomic model where the government aims at internal and external balance. We find that, in this setting, monetary policy is more stabilizing for the economy than trade policy, except when the internal transmission channel of monetary policy is muted (at the zero-lower bound). One implication is that, in normal times, a country will more likely react to a trade "aggression" through monetary easing rather than through a tariff increase. The result is reversed at the ZLB.

\section{Keywords}

Tariffs, Exchange Rates, Trade Elasticities, Protectionism.

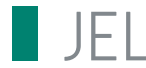

F13, F14, F31, F60.

\section{Working Paper}

\section{CEPH}

CEPII (Centre d'Etudes Prospectives et d'Informations Internationales) is a French institute dedicated to producing independent, policyoriented economic research helpful to understand the international economic environment and challenges in the areas of trade policy, competitiveness, macroeconomics, international finance and growth.
CEPII Working Paper

Contributing to research in international economics

C C CEPII, PARIS, 2018

All rights reserved. Opinions expressed in this publication are those of the author(s) alone.

$\begin{array}{ll}\text { Editorial Director: } & \text { CEPII } \\ \text { Sébastien Jean } & \text { 20, avenue de Ségur } \\ & \text { TSA 10726 } \\ \text { Production: } & 75334 \text { Paris Cedex } 07 \\ \text { Laure Boivin } & +33153685500 \\ & \text { www.cepii.fr } \\ \text { No ISSN: 1293-2574 } & \text { Press contact: presse@ }\end{array}$




\section{Introduction}

After decades of continuous progress towards global trade integration, the issue of protectionism has come back at the top of the policy agenda since the 2010s. In 2018, the US administration decided unilaterally to raise a number of import tariffs. ${ }^{1}$ While the reasons for such reversal are diverse and complex, they may appear as a delayed reaction to "deindustrialization" and increased inequalities observed since the 1990s (see Evenett, 2012). Simultaneously, acrimony about non-cooperative monetary policies have been on the rise since the global financial crisis (Mantega, 2010). The G20 rule that monetary policy should not be used for "competitive devaluation" ${ }^{2}$ was tested several times. As a matter of fact, several researchers have shown that the zero lower bound (ZLB) increases the risk of non cooperative policies: governments have incentives to use beggar-thy-neighbour policies such as tariffs or currency devaluations to attract global demand at the expense of their trading partners (Caballero et al., 2015; Eggertsson et al., 2016; Gourinchas and Rey, 2016).

When combined with an export subsidy, a tax on imports theoretically has the same impact as a currency devaluation (see Farhi et al., 2013). In both cases, the relative price of foreign suppliers is increased in the short term; depending on pass-through effects and on trade elasticities, the volume of imports falls while the volume of exports increases. In the longer run, the upward adjustment of domestic prices progressively offsets these effects.

In practice, however, there are significant differences between tariffs and currency changes. In particular, tariffs are a policy variable ${ }^{3}$ while exchange rates are generally determined on financial markets, even though they react to policy decisions from fiscal and monetary authorities. As a result, changes in tariffs may be considered more persistent than exchangerate fluctuations, thus affecting the decision by the exporter to offset the induced change in relative prices by adjusting his mark-up, and of the importer to switch with another supplier. Additionally, import tariffs may be sector-specific, whereas a currency devaluation affects all

\footnotetext{
${ }^{1}$ This has triggered an intense policy debate, see e.g. Coeuré (2018).

${ }^{2}$ See, e.g. the G20-finance communiqué of Buenos Aires, 20 March 2018.

${ }^{3}$ Grossman and Helpman (1994) and Grossman and Helpman (1995) studied the impact of lobbies pressuring government to increase trade protectionism.
} 
sectors simultaneously, with also larger effect on the cost of imported inputs.

Finally, tariffs and exchange rates also differ in their welfare implications. While trade wars are undeniably a negative-sum game (despite the fact that they provide revenues to the government), monetary policies that tend to depreciate national currencies may in some cases be beneficial to foreign countries, particularly if the latter choose appropriate policy responses. ${ }^{4}$ When the interest rate is at the zero lower bound, Caballero et al. (2015) argue that a "currency war" is a zero-sum game, whereas Jeanne (2018) finds that currency wars have a positive impact on welfare, as opposed to the large negative impact of trade wars. ${ }^{5}$

The interplay between tariffs and exchange rates is recognized by the WTO whose Article XV may authorize trade restrictions against a "currency manipulator", after the currency manipulation has been confirmed by the International Monetary Fund. In turn, Article IV of the IMF prohibits the manipulation of exchange rates in order "to prevent effective balanceof-payment adjustment or to gain unfair competitive advantage". Still, it is difficult to prove currency manipulation. Bergsten and Gagnon (2012) consider that the conjunction of rising foreign-exchange reserves and a current-account surplus defines a currency manipulator, for countries whose GDP per capita is above the world median. However, the IMF accepts foreign-exchange interventions or even capital controls to mitigate a large and sudden capital inflow (see Ostry et al., 2010). Currency manipulation would then be declared only in the case of prolonged under-valuation of the currency with respect to an "equilibrium" exchange rate that needs to be calculated and agreed upon. As a matter of fact, no country has ever been declared a "currency manipulator" by the IMF.

Still, at the national level, tariffs are often intended to be used as retaliation against perceived undervaluation by trading partners. As a matter of fact, exchange-rate variations have been shown to be a significant determinant of protectionism. In particular, Eichengreen and Irwin (2010) show how those countries that remained in the gold standard in the 1930s were more prone to increasing their import tariffs. ${ }^{6}$ In the United States, Congress can impose

\footnotetext{
${ }^{4}$ See Eichengreen (2013), Blanchard (2017) and Jeanne (2018).

${ }^{5}$ This result comes from the fact that a trade war depresses global demand, whereas a currency war is stabilizing to the extent that it is carried out through expansionary monetary policies.

${ }^{6}$ For post-war evidence, see Knetter and Prusa, 2003; Bown and Crowley, 2013; Georgiadis and Gräb, 2013;
} 
a rise in tariffs on a country that is found to be a "currency manipulator", although the semiannual report of the US Treasury on foreign-exchange policies has routinely concluded that no major country fulfills the criteria of currency manipulation.

Surprisingly, there is limited evidence on the compared effects of currency undervaluation and tariffs on trade flows. ${ }^{7}$ While standard trade models such as Krugman (1979) or Eaton and Kortum, 2002 would feature similar trade elasticities with respect to tariffs and to the exchange rate, existing studies have found the former to be much larger than the latter (see e.g. Fitzgerald and Haller, 2014, Fontagné et al., 2017, or the meta-analysis of Head and Mayer, 2014). However, this literature relies on firm-level data for a particular country (Ireland for Fitzgerald and Haller, 2014, France for Fontagné et al., 2017). We are not aware of a systematic comparison of trade elasticities to tariffs and to the exchange rate in a more general, multi-country framework.

As for the macroeconomic literature, it has recently studied the equivalence between import tariffs / export subsidies and exchange rates within a DSGE framework where the exchange rate appreciates endogenously following an increase in import duties and export subsidies, with Taylor-type monetary policy (see Lindé and Pescatori, 2017; Barattieri et al., 2018; Barbiero et al., 2018; Eichengreen, 2018; following Staiger and Sykes, 2010). These results however typically rely on similar pricing behavior and similar demand elasticities with respect to tariffs and to the exchange rate, and on monetary policy being geared at domestic objectives. Taylor (2016) argues that a rule-based monetary system, where each central bank follows an inward-looking Taylor rule, will not be prone to "currency wars": In such a rulebased world, there is no space for a currency war. Consistently, a literature has developed to try to specify the concept of currency manipulation as a deviation from the standard, general Bown and Crowley, 2014

${ }^{7}$ In the literature, one of the two variable is often taken into account by fixed effects when estimating the impact of the other one. For instance, Berthou (2008) and Anderson et al. (2013) develop a gravity model at the industry level which allows them to estimate the impact of the real exchange rates, but trade barriers are controlled through fixed effects. Using a different methodology, de Sousa et al. (2012) derive and estimate a ratio-type gravity equation at the industry level for a large number of countries, which allows them to estimate the impact on trade of tariffs and relative prices. However, they do not estimate the impact of the exchange rate itself. Relative prices react to the exchange rate depending on pass-through effects, which may vary across sectors and countries. 
equilibrium model. ${ }^{8}$

In this paper, we consider monetary policy as a policy instrument that may be used in a discretionary way by the government of a country to stabilize a combination of the output gap and the trade balance after a shock. Hence we depart from the DSGE literature by studying a short-term equilibrium where prices are fixed and monetary policy has an external objective on the top of the domestic one.

We first estimate elasticities of trade to tariffs and to the exchange rate within the same empirical specification, based on product-level (HS6) bilateral trade flows for 110 countries over 1989-2013. We adapt the gravity model to account for the specific features of the real exchange rate, which is neither product-level nor trully dyadic (see Head and Mayer, 2014). The results indicate that the effect of tariffs is much larger than that of exchange-rate movements. In our preferred specification, a $1 \%$ depreciation of the exporter's currency is associated with a rise in exports by $0.5 \%$ (in current dollars), whereas a 1 percentage point tariff cut in the destination country leads to a rise in exports by $1.4 \%$. Hence, a $1 \%$ currency devaluation is "equivalent" to a $0.34 \mathrm{pp}$ tariff cut: tariffs are 2.9 times more "powerful" than the exchange rate. Although the estimates vary across the specifications, the relative impact of tariffs with respect to the exchange rate is surprisingly stable, from 2.9 to 3.4. Hence, exchange rates and tariffs have significantly different impacts on trade.

In a second step, we investigate the policy implications of our estimations within a simple macroeconomic model adapted from Blanchard (2017). We assume that the policy-maker of an open economy has two objectives: internal and external equilibrium. ${ }^{9}$ Faced with a negative shock on external demand, the policy-maker will cut the home interest rate and let the currency depreciate, or increase the tariff on imports. Hence, the two instruments are found partly substitutes. However, if both instruments are available, they are used as

\footnotetext{
${ }^{8}$ See Cline and Williamson (2010); Bergsten and Gagnon (2012); Eichengreen (2013); Blanchard (2017).

${ }^{9}$ Blanchard (2017) examines the scope of international coordination by using a two-country MundellFleming model where both domestic and foreign economies care about the deviation of output from its potential level, and about the deviation of net exports from zero. To reach these two objectives, the two economies can use either fiscal or monetary policy, or combine both policies. In our model, the government rather uses monetary and/or trade policies to reach its internal and external objectives. Fiscal policy is considered non-available, e.g. due to excess indebtedness, and the proceeds from import duties cannot be used to stimulate internal demand.
} 
complements. In particular, one may be used in a pro-competitive way while the other one will be set so as to stabilize the purchasing power of domestic households.

We show that, over the range of our estimated equivalence ratio between both instruments, the monetary reaction to a negative demand shock is always to cut the domestic interest rate. If both instruments are available, the monetary expansion is accompanied with a trade policy that depends on the nature of the shock. It can be optimal to cut the tariff in order to limit the negative impact of the currency depreciation on households' purchasing power. However, when the internal transmission channel of monetary policy is less effective (at the zero lower bound), the optimal policy mix in reaction to a negative demand shock is reversed: it becomes optimal to increase the import tariff while letting the home currency appreciate in order to compensate the negative impact of the tariff on consumers' purchasing power. Hence, according to our results, the ZLB may raise the likelihood of non-cooperative policies, but more through tariffs than through monetary policies. In normal times, a country will react to a trade "aggression" through the monetary instrument rather than through trade retaliation. But at the ZLB it will respond through trade retaliation. The model extension to a two-country setting confirms our conclusions.

The rest of the paper is organized as follows. Section 2 briefly reviews the existing literature on trade elasticities. Section 3 outlines our econometric methodology. Section 4 presents the data and key stylized facts. Section 5 reports the main empirical results and a few robustness checks. Section 6 studies the policy implications within a stylized macroeconomic model. Section 7 concludes the paper.

\section{Trade elasticities compared: the literature}

The empirical literature on trade elasticities has been summarized in the meta-analysis of Head and Mayer (2014). Strikingly, the elasticities to tariffs and to the exchange rate are generally estimated separately. One reason is that the logarithm of the real exchange rate is colinear to

the fixed effects used in standard gravity equations (see Section 3), which precludes studying the impact of the real exchange rate on trade. This identification problem is sometimes 
circumvented by substituting industry-specific relative prices to the real exchange rate as an explanatory variable. For instance, de Sousa et al. (2012) use a ratio-type gravity equation for 151 countries over 1980-1996. The ratio of exports to a specific country over total exports is then regressed on the relative price and the bilateral tariff. They find that the effect of a tariff is, on average, ten times larger than that of relative prices. The problem with such estimation is that relative prices are not a policy variable, since they incorporate the extent of exchange-rate pass-through that may vary across products and destination countries. Hence, the impact of relative prices cannot be directly compared to that of tariffs.

Several papers have focused only on the exchange-rate elasticity. For instance, Leigh et al. (2015) estimate exchange rate pass through and price elasticity of volumes for a large set of countries at the macroeconomic level. Overall, they find that a $10 \%$ real effective depreciation in the exporter's currency is associated with a $6.4 \%$ rise in the value of exports (in the exporter's currency), going up to a $8.4 \%$ increase at the sector-level. Similarly, Bussière et al. (2016) provide a set of price and income elasticities for 51 countries, using a database of bilateral trade flows covering about 5,000 products. In their estimation with several fixed effects, a 10\% depreciation of the exporter's currency increases the value of exports (again, in the exporter's currency) by 6\%. Berman et al. (2012) use French firm-level data from 1995 to 2005 and find that a $10 \%$ depreciation is associated to a $6 \%$ increase in the value of exports of the average firm. Using a unique cross-country micro-based dataset of exporters available for 11 European countries, Berthou and Dhyne (forthcoming) find that a 10\% appreciation of the real effective exchange rate tends to reduce the exports value in euro of the average firm by $5 \%$ to $8 \%$.

In turn, Berthou and Fontagné (2016) estimate the tariff elasticity of French exports using firm-level data. Their estimates indicate that a $10 \%$ increase in tariff in the destination decreases exports by $25 \%$ on average. This is consistent with Fontagné et al. (2017) who simultaneously estimate export elasticities to the real exchange rate and to tariffs at the firm level for France, and find that a 10\% appreciation of the domestic currency decreases exports 
(expressed in the exporter's currency) by $6 \%$ while a $10 \%$ increase in the power of the tariff ${ }^{10}$ decreases exports by almost $20 \%$.

Here we want to rely on multi-country estimations in order to inform the currency war versus trade war debate with appropriate quantification. We use product-level bilateral data for 110 countries and adapt the gravity model to address the identification problem mentioned above.

\section{Empirical methodology}

The empirical trade literature has extensively shown that bilateral trade flows are well explained by the gravity model where exports from country $i$ to country $j$ depend on the economic size of both countries (corrected for their multilateral "resistence"), on the geographic distance between them and on a set of dummy variables such as common border, common language or membership of a free trade area. ${ }^{11}$

The recent literature has preferred to rely on the following specification where country $i$ 's exports to country $j$ of good $k$ during year $t, X_{i j k t}$, is explained by a series of fixed effects:

$$
\ln X_{i j k t}=\lambda_{i k t}+\mu_{j k t}+\nu_{i j}+\epsilon_{i j k t}
$$

where $\lambda_{i k t}, \mu_{j k t}$ and $\nu_{i j}$ are fixed effects in the dimensions indicated by the indices, and $\epsilon_{i j k t}$ is the residual. ${ }^{12}$

Adding the logarithm of the bilateral real exchange rate of country $i$ against country $j$, $\ln R E R_{i j t}$, and the power of the tariff imposed by country $j$ on product $k$ imported from country $i, \ln (1+\tau)_{i j k t}$, we get:

$$
\ln X_{i j k t}=\alpha_{1} \ln R E R_{i j t}+\alpha_{2} \ln (1+\tau)_{i j k t}+\lambda_{i k t}+\mu_{j k t}+\nu_{i j}+\epsilon_{i j k t}
$$

\footnotetext{
${ }^{10}$ If $\tau$ denotes the tariff rate, the power of the tariff is $\ln (1+\tau)$. Using the power of the tariff rather than the tariff itself allows us to circumvent the fact that the tariff is often zero (given the large network of free trade agreements), while still estimating an elasticity. For a small tariff, we have $\ln (1+\tau)=\tau$.

${ }^{11}$ The theoretical underpinnings of the gravity model have been proposed by Anderson (1979) and Anderson and Wincoop (2003).

${ }^{12}$ The "naive" gravity specification that relies on GDPs is plagued with an omitted variable bias notably related to multilateral resistance (see Baldwin (2007)).
} 
The problem with Equation (2) is that the real exchange rate is colinear to the exporterproduct-time fixed effect $\left(\lambda_{i k t}\right)$ and to the importer-product-time fixed effect $\left(\mu_{j k t}\right)$, since it is the difference between countries $i$ and $j$ log-price indices corrected for the bilateral nominal exchange rate. One way to get around this identification issue is to substitute an exporterproduct fixed effect to the usual exporter-product-time fixed effect, and to complement it with a vector of controls $Z_{i t}$ that will capture the variance in the exporter-time dimension. ${ }^{13}$ We therefore estimate the following equation:

$$
\ln X_{i j k t}=\alpha_{1} \ln R E R_{i j t}+\alpha_{2} \ln (1+\tau)_{i j k t}+\alpha_{3} Z_{i t}+\lambda_{i k}+\mu_{j k t}+\nu_{i j}+\epsilon_{i j k t}
$$

The dependent variable is the logarithm of exports from country $i$ to country $j$ in product $k$ during year $t$, expressed in current dollar. The first variable of interest is the logarithm of the bilateral real exchange rate between country $i$ and country $j$ in year $t$, defined such that an increase in the real exchange rate is an appreciation of the exporter's currency. The second variable of interest is the logarithm of the power of the tariff, defined as the log of one plus the bilateral tariff imposed by importer $j$ for product $k$ coming from country $i$ in year $t$. The vector of exporter-time controls $Z_{i t}$ includes the exporter's GDP in current dollar and a crisis dummy (see data section).

Alternatively, Equation (3) is estimated while replacing the exporter-importer fixed effect, $\nu_{i j}$, by a set of standard gravity controls, some of which may vary over time: free trade agreements, single market, common currency, contiguity, common language, colonial history, and the logarithm of the distance. ${ }^{14}$

\footnotetext{
${ }^{13}$ See Head and Mayer, 2014. We assume that trade flows are more sensitive over time to demand-side variables than to supply-side ones. Hence we keep the full set of fixed effects on the importer side, and choose to relax the time dimension on the exporter's fixed effect. We check for the robustness of this choice.

${ }^{14}$ We also tried to estimate Equation (3) with exporter-importer-product fixed effects. However the variability of the tariffs in the time dimension happened to be too limited for this estimation to be carried out.
} 


\section{Data}

\subsection{Data sources}

The dataset covers 110 countries, from advanced to developing economies, ${ }^{15}$ from 1989 to 2013, with annual data. In 2013, these countries represented $83 \%$ of world exports. We use harmonized bilateral trade data at the detailed HS6 product level from the BACI database (Gaulier and Zignago, 2010) where trade flows are expressed in current dollar. ${ }^{16}$

Bilateral real exchange rates are from the IMF or computed by the US Department of Agriculture, using IMF data. Yearly-average nominal bilateral exchange rates are corrected for consumer prices indices. ${ }^{17}$ Gross domestic product in current dollar is taken from the Penn World Tables. The gravity controls are from Head et al. (2010), and de Sousa (2012). Finally, the crisis dummy is constructed based on Laeven and Valencia (2012). It refers to banking crises, currency crises and sovereign debt crises.

There exist three types of tariffs within the World Trade Organization: Most-Favored Nation (MFN) tariffs, Preferential Trade Agreement (PTA) tariffs and bound tariffs. ${ }^{18}$ MFN tariffs are what countries have promised to impose on all WTO members not included in a PTA. Both MFN and PTA tariffs can vary as long as they do not get higher than the bound tariff, ${ }^{19}$ which is individually negociated at the WTO. In pratice, MFN tariffs are the highest tariffs WTO members can charge one another. Here we rely on the TRAINS database (UNCTAD), at the HS6 product level. When countries $i$ and $j$ are covered by a PTA, we use the corresponding tariffs. Otherwise, we retain the MFN tariffs. In all cases, tariffs are measured at the beginning of year $t .^{20}$

\footnotetext{
${ }^{15}$ See country list in Appendix A.

${ }^{16}$ Using original data from the COMTRADE database, BACI is constructed by reconciling the declarations of the exporter and the importer, providing a complete dataset for exports, at the HS6-digit product level.

${ }^{17}$ Although a currency devaluation concerns the nominal exchange rate, governments generally want to monitor the real exchange rate, which is closer to price competitiveness. Except in high-inflation countries, the real exchange rate closely follows the nominal one in the short term.

${ }^{18}$ See http://wits.worldbank.org/. This database does not include temporary trade barriers, such as antidumping duties, countrevailing duties and safeguard measures.

${ }^{19}$ The gap between the bound and applied MFN rates is called the binding overhang. It is generally greater for developing countries than for advanced economies.

${ }^{20}$ The database includes ad valorem-equivalents of specific duties and import quotas, which may vary with prices. Since specific duties and import quotas are mostly used in agriculture, we present robustness tests while restricting the sample to manufacturing products.
} 
Table 1: Summary statistics

\begin{tabular}{lccccc}
\hline \hline & Mean & Within s.d. & Median & 1st decile & 9th decile \\
\cline { 2 - 6 } & & & & & \\
Levels & 5.70 & 2.9 & 0 & 0 & 17.5 \\
Tariffs $(\%)$ & 103.5 & 15.2 & 100 & 73 & 136.6 \\
$\begin{array}{l}\text { Real exchange rate }(100=2010) \\
\text { Variations }\end{array}$ & 0.9 & 9 & 0.6 & -1.7 & 3.6 \\
$\begin{array}{l}\text { Real exchange rate }(\%) \\
\text { Tariffs }(\mathrm{pp})\end{array}$ & -0.27 & 1.8 & 0 & -0.4 & 0 \\
\hline \hline
\end{tabular}

Notes: The real exchange rate index is based 100 in 2010. The variations in the real exchange rate are not symetrical due to the different number of occurence in the database, depending on the number of products exchanged by the country-pair at time t.

\subsection{Stylised facts}

Table 1 presents some summary statistics for tariffs and real exchange rates. Over our sample, the average tariff is of $5.70 \%$, but the median is $0 \%$. Extreme tariffs are rare as evidenced by the $17.5 \%$ tariff value for the last decile. The real exchange rate is much more volatile than tariffs: on average, the (within) standard deviation is $15.2 \%$ for the former but only $2.9 \%$ for the latter.

Figure 1 illustrates the asymmetric evolution of tariffs (PTAs and MFNs) from 1990 to 2013. The black line represents the average tariff, which is more than halved between 1990 and 2013. The dark-grey bars represent the yearly share of tariff increases, which is calculated as the number of tariff increases in percent of total tariff lines at the exporter-importerproduct level, weighted by the share of trade flows that are affected by the tariff variation. Tariff increases pick in 1999 but they generally remain lower than $1 \%$ of all weighted tariff lines. Finally, the light-grey bars represent the share of tariff cuts, calculated with the same methodology. These bars reflect the intensification of trade liberalization starting in 1996, with a pick in 2002 and subsequent weakening along the downward trend of tariffs. ${ }^{21}$ In 2013 , $62 \%$ of the available tariffs in our sample are equal to zero, versus $50 \%$ in 1990.

The downward trend in tariffs is further illustrated when looking at the non-zero variations

\footnotetext{
${ }^{21}$ Trade liberalization took place both through cuts in MFN tariffs, and through an increasing number of regional PTAs, see Key statistics and trends in trade policy 2015, UNCTAD.
} 
Figure 1: Tariffs variations

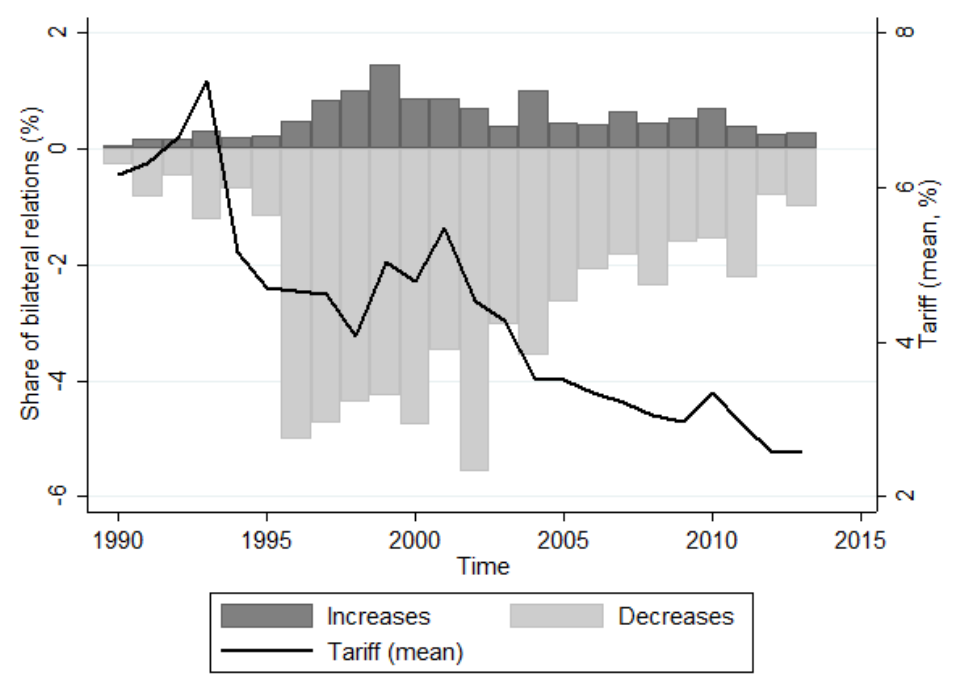

in tariffs: two third of them are decreases. The average decrease is of 4.9 percentage points. The cuts range from -0.1 percentage point ${ }^{22}$ to $-3,000$ pp. Increases are less frequent than cuts, but they are generally of larger amount: $+5.6 \mathrm{pp}$. on average.

Tariff hikes are generally short lived over the period of investigation, in contrast with tariff cuts (Figure 2): on average, an increase is offset by half a year after, whereas a decrease is only followed by a slight increase the year after.

Figure 2: Lifespan of tariff variations
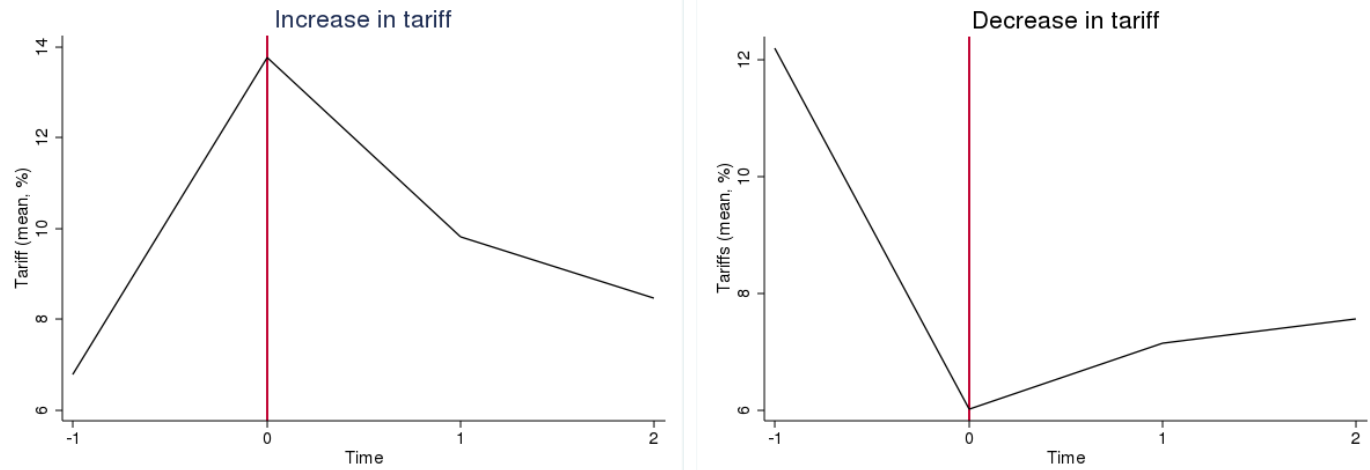

Note: Time 0 corresponds to the year of the tariff increase or cut (compared to time -1 ).

${ }^{22}$ The sample includes tariff-equivalents of quotas on agricultural products wich may artificially increase the count of variations. Thus, we exclude variations of less than 0.1 percentage point. 
It is sometimes argued that exchange-rate variations are short-lived, hence they should have less impact on trade flows than tariff variations. Figure 3 shows that this is not the case for bilateral real exchange rates: there is no reversal of an appreciation nor of a depreciation within the two following years. ${ }^{23}$

Figure 3: Lifespan of RER variations
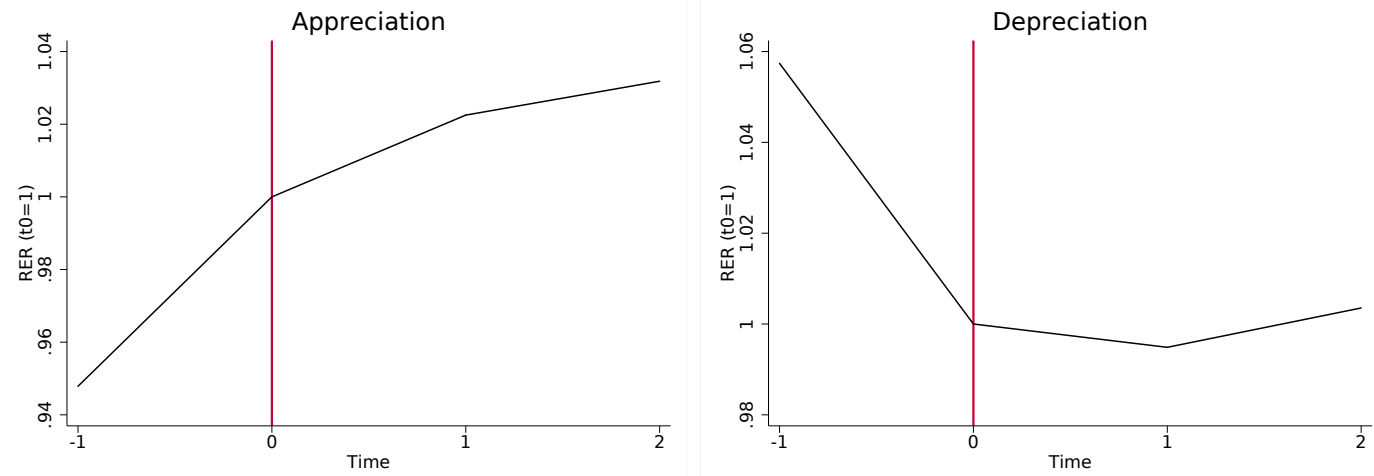

Note: Time 0 corresponds to the year of the real exchange rate appreciation or depreciation (compared to time -1).

\section{$5 \quad$ Results}

\subsection{Baseline results}

Table 2 reports our baseline results. In Column (1), the standard gravity equation (Equation (1)) is augmented with the tariffs, which are not colinear to the fixed effects. The coefficient on tariffs is negative and significant at the 1 percent level: a $1 \%$ cut in the power of the tariff in the destination country (Tarif $f_{i j k t}$ representing $\left.\ln \left(1+\tau_{i j k t}\right)\right)$ implies a $1.9 \%$ increase in exports to this country. Or equivalently, a 1 percentage point cut in the tariff $\tau_{i j k t}$ results in a $1.9 \%$ increase in exports expressed in current dollar.

Column (2) presents the results of the same estimation when $i k t, j k t$ and $i j$ fixed effects are replaced by the logarithm of both countries' GDPs, $G D P_{i t}$ and $G D P_{j t}$ respectively, together with $i j k$ and time fixed effects. ${ }^{24}$ The coefficients on the exporter's and the importer's GDP

\footnotetext{
${ }^{23}$ The literature on real exchange rates suggests mean-reversion over the long term only for advanced economies, and with a half-live of about 4-5 years (see Rogoff et al., 1995).

${ }^{24}$ We also cluster the results in the $i j$ dimension.
} 
Table 2: Baseline results

\begin{tabular}{|c|c|c|c|c|c|c|c|}
\hline & & & Dependen & variable: $E$ & xports $s_{i j k t}$ & & \\
\hline & $(1)$ & $(2)$ & $(3)$ & $(4)$ & $(5)$ & $(6)$ & $(7)$ \\
\hline & $\begin{array}{l}\text { Standard } \\
\text { gravity }\end{array}$ & $\begin{array}{l}\text { Simple } \\
\text { gravity }\end{array}$ & $\begin{array}{c}\text { Extended } \\
\text { gravity }\end{array}$ & Baseline & $\begin{array}{c}\text { Controls } \\
i t\end{array}$ & $\begin{array}{l}\text { Exporter's } \\
\text { currency }\end{array}$ & Volume \\
\hline$R E R_{i j t}$ & & & $\begin{array}{c}-0.300^{* * *} \\
(-8.98)\end{array}$ & $\begin{array}{c}-0.474^{* * *} \\
(-8.02)\end{array}$ & $\begin{array}{c}-0.472^{* * *} \\
(-7.99)\end{array}$ & $\begin{array}{c}-0.673^{* * *} \\
(-24.04)\end{array}$ & $\begin{array}{c}-0.269^{* * *} \\
(-6.825)\end{array}$ \\
\hline Tarif $f_{i j k t}$ & $\begin{array}{c}-1.864^{* * *} \\
(-183.16)\end{array}$ & $\begin{array}{c}-0.546^{* * *} \\
(-8.03)\end{array}$ & $\begin{array}{c}-0.637^{* * *} \\
(-9.42)\end{array}$ & $\begin{array}{c}-1.366^{* * *} \\
(-14.88)\end{array}$ & $\begin{array}{c}-1.365^{* * *} \\
(-14.88)\end{array}$ & $\begin{array}{c}-1.823^{* * *} \\
(-12.36)\end{array}$ & $\begin{array}{c}-1.454^{* * *} \\
(-11.84)\end{array}$ \\
\hline$G D P_{i t}$ & & $\begin{array}{c}0.520^{* * *} \\
(13.17)\end{array}$ & $\begin{array}{c}0.617^{* * *} \\
(17.52)\end{array}$ & $\begin{array}{c}0.694^{* * *} \\
(12.35)\end{array}$ & $\begin{array}{c}0.693^{* * *} \\
(12.31)\end{array}$ & $\begin{array}{c}0.958^{* * *} \\
(88.28)\end{array}$ & \\
\hline$G D P_{j t}$ & & $\begin{array}{c}0.569^{* * *} \\
(25.55)\end{array}$ & $\begin{array}{c}0.440^{* * *} \\
(14.85)\end{array}$ & & & & \\
\hline Crisis $_{i t}$ & & & & & $\begin{array}{c}-0.011^{*} \\
(-1.86)\end{array}$ & & \\
\hline Real $G D P_{i t}$ & & & & & & & $\begin{array}{c}1.107^{* * *} \\
(12.88)\end{array}$ \\
\hline FE ikt - jkt - ij & Yes & No & No & No & No & No & No \\
\hline FE ijk - t & No & Yes & Yes & No & No & No & No \\
\hline FE ik - jkt - ij & No & No & No & Yes & Yes & Yes & Yes \\
\hline Observations & $63,746,656$ & $63,363,339$ & $61,611,845$ & $63,203,049$ & $63,203,049$ & $59,751,140$ & $62,409,613$ \\
\hline R-squared & 0.679 & 0.771 & 0.772 & 0.640 & 0.640 & 0.765 & 0.691 \\
\hline
\end{tabular}

Notes: standard errors are clustered at the country-pair level, t-stats are in parentheses. All variables are in logarithm except for the inflation; ; all nominal variables are expressed in US dollars. The level of significance is the following: $* * * \mathrm{p}<0.01,{ }^{* *} \mathrm{p}<0.05,{ }^{*} \mathrm{p}<0.1$ 
are positive and highly significant. ${ }^{25}$ The coefficient on import tariffs is still negative and significant at the 1 percent level, but its size is reduced, suggesting that our two control variables - $G D P_{i t}$ and $G D P_{j t}$ - hardly capture the heterogeneity in the country-product-time dimension.

In Column (3), we keep the same controls and fixed effects as in Column (2), but now add the logarithm of the real exchange rate. The four coefficients are significant at the 1 percent confidence level, with the expected signs. On average, a $1 \%$ depreciation in the real exchange rate of the exporter's country (decrease in $R E R_{i j t}$ ) implies a $0.3 \%$ increase in its exports in dollar, while a $1 \%$ cut in the power of the tariff in the destination country involves a $0.6 \%$ increase in exports. Interestingly, the coefficient on the power of the tariff is not significantly different from the one found in Column (2).

In Column (4) the destination country's GDP is replaced by a destination-product-time fixed effect in order to fully capture heterogeneity in the $j k t$ dimension, and the other fixed effects are adjusted, consistent with Equation (3). The vector of controls $Z_{i t}$ here is limited to the exporter's GDP, whereas Column (5) adds the crisis dummy. The residuals are still clustered at the country-pair level. Both columns are very similar. A $1 \%$ depreciation of the real exchange rate is associated with a $0.5 \%$ increase in exports, while a $1 \%$ cut in the power of the tariff in the destination country is associated with a $1.4 \%$ increase in exports. Hence, a $1 \%$ depreciation of the real exchange rate in the destination country is "equivalent", in terms of exports, to a $0.34 \%$ tariff cut in the destination country: the tariff cut is 2.9 times more "powerful" than an exchange-rate depreciation. Since the coefficient on the crisis dummy is significant only at the 10 percent confidence level, we consider Column (4) as our baseline results. Compared to Column (3), we fully account for possible omitted variables in the destination country, although not in the origin country. The coefficient on the tariff is close to the one found with the standard gravity specification (Column (1)), which confirms the adequacy of our specification choice.

In Column (6), we repeat the baseline estimation while expressing the dependent variable

\footnotetext{
${ }^{25}$ Note that size and time effects are already captured by the fixed effects.
} 
and the exporter's GDP in the exporter's currency rather than in US dollar. ${ }^{26}$ Both elasticities are magnified compared to the baseline estimation: a $1 \%$ depreciation of the home currency in real terms now involves a $0.7 \%$ increase in the home-currency value of exports, whereas a $1 \%$ cut in the power of the tariff in the destination country raises exports by $1.8 \%$. Hence a $1 \%$ depreciation is now "equivalent" to a $0.37 \%$ tariff cut: the tariff cut is 2.6 times more "powerful" than the depreciation - a ratio not much different than in the baseline estimation. Interestingly, the elasticities found both for tariffs and for the exchange rate are close, although slightly lower than those separately in the literature (see Section 2). ${ }^{27}$

Finally, Column (7) presents the results of the estimation in volumes, trade flows being deflated by unit values. Both elasticities are smaller than in the baseline, except the estimate on real GDP which is now equal to unity. A $1 \%$ depreciation of the real exchange rate is now associated with a $0.27 \%$ increase in export volumes, while a $1 \%$ cut in the power of the tariff in the destination country is associated with a $1.5 \%$ increase in export volumes. Hence, the equivalence ratio between the two variables (5.5) is higher than for estimations run on values but it remains around the same orders of magnitude.

Comparing Columns (6) and (7) allows us to get a quantification of pricing-to-market, since (6) is expressed in the exporter's currency whereas (7) is in volume. If a $1 \%$ appreciation in the exporter's currency reduces its exports by $0.67 \%$ in his own currency but only by $0.27 \%$ in volume, it must be that the export price in the exporter's currency declines by $0.67-$ $0.27=0.4 \%$. Similarly, if a $1 \mathrm{pp}$ increase in the destination countries' import tariff reduces exports by $1.82 \%$ in the exporter's currency but by only $1.45 \%$ in volume, it must be that the export price in the exporter's currency falls by $1.82-1.45=0.37 \%$. Interestingly, the extent of pricing-to-market is similar in both cases, implying a pass-through coefficient of $0.6 .^{2829}$

\footnotetext{
${ }^{26}$ The number of observations varies because of missing values in the nominal exchange rate used to compute the variables in the exporter's currency. We have checked however that there is no selection bias.

${ }^{27}$ By comparing elasticities estimated separately, Head and Mayer (2014) find trade elasticities to tariffs to be roughly 5 times higher than trade elasticities to exchange rates. However the methodologies may not be comparable for the two average estimates. It should be reminded here that the literature generally finds higher elasticities the more detailed the database used. Consistently, our estimation run on aggregate, bilateral trade flows (dropping the product dimension) leads to smaller estimates for both elasticities.

${ }^{28}$ Feenstra (1989) also found symmetric pass-through for tariffs and the exchange rate on the US price of Japanese cars, trucks and motorcycles over the 1974:1-1987:1 period.

${ }^{29}$ Our pass-through estimate is slightly lower than those found by Boz et al. (2017), while our trade elasti-
} 


\subsection{Robustness checks}

Table 3 presents a set of robustness checks. Column (1) reproduces the baseline estimation. In Column (2), we replace the exporter-importer fixed effect by a standard set of gravity controls, some of which vary over time: common border dummy (Contiguity $y_{i j}$ ), common language dummy $\left(\right.$ Language $\left._{i j}\right)$, former colonial link dummy (Colony $\left.y_{i j}\right)$, geographic distance $\left(\right.$ Distance $\left._{i j}\right)$, regional trade agreement $\left(R T A_{i j t}\right)$, a common currency (Currency $\left.{ }_{i j t}\right)$, and common membership to the European Union trade $\left(E U_{i j t}\right)$. All added variables are significant at $1 \%$ with the expected sign. Using the standard errors in brackets, we see that the estimates on the real exchange rates and on the tariff are only slightly different from Columns (1).

In Column (3), we limit the sample to the pre-crisis, 1989-2007 period. The two coefficients of interest are not significantly different from baseline.

Next, we come back to the baseline specification but add the first lag of the three variables, in order to account for possible delayed effects of exchange rates and tariffs. The estimates are reported in Column (4). The three lagged variables are highly significant, with expected signs. The coefficient on the contemporaneous exchange rate is not much affected, unlike that on the tariff which is reduced but remains significant at $1 \%$. It should be noted here that tariffs are recorded at the beginning of the year whereas real exchange rates are yearly averages. This difference may be reinforced by higher uncertainty concerning the exchange rates (which moves every year) compared with the tariffs (which experience less frequent changes). ${ }^{30} 31$

On the whole, the elasticity of exports to the real exchange rate are found relatively stable across the different specification, around $0.43-0.47$ if we restrict ourselves to the estimations carried out over the whole sample without lags. That on tariffs varies approximately from 1.3 to 1.6. We can conclude that a tariff cut in the destination country is 2.8 to 3.7 times more

cities are higher, consistent with the fact that, unlike Boz et al. (2017), we are working on product-level data. Note that we are not studying here the role of dollar invoicing because we are interested in exchange-rate policies vis-à-vis all other currencies.

${ }^{30}$ In an additional exercise, we tested for the impact of nominal exchange-rate volatility on trade flows, but the variable proved non-significant.

${ }^{31}$ In an additional exercise (not shown here), we controlled for the possible colinearity between tariffs and exchange rate by orthoganalizing the tariff variable: we regressed the logarithm of one plus the tariff on the logarithm of the real exchange rate and then introduced the residual of this equation in the baseline estimation instead of the tariff. The results were left unaffected in sign and in magnitude. 
Table 3: Robustness checks

\begin{tabular}{|c|c|c|c|c|}
\hline & \multicolumn{4}{|c|}{ Dependent variable: Exports $s_{i j k t}$} \\
\hline & $(1)$ & $(2)$ & $(3)$ & $(4)$ \\
\hline & Baseline & $\begin{array}{l}\text { Gravity } \\
\text { controls }\end{array}$ & $\begin{array}{l}\text { Pre-crisis } \\
1989-2007\end{array}$ & $\begin{array}{c}\text { Lagged } \\
\text { variables }\end{array}$ \\
\hline$R E R_{i j t}$ & $\begin{array}{c}-0.474^{* * *} \\
(-8.02)\end{array}$ & $\begin{array}{c}-0.431 * * * \\
(-7.936)\end{array}$ & $\begin{array}{c}-0.514^{* * *} \\
(-7.880)\end{array}$ & $\begin{array}{c}-0.505^{* * *} \\
(-6.401)\end{array}$ \\
\hline & $[0.059]]$ & {$[0.054]$} & {$[0.065]$} & [0.079] \\
\hline Tariff $f_{i j k t}$ & $-1.366^{* * *}$ & $-1.645^{* * *}$ & $-1.467 * * *$ & $-0.853^{* * *}$ \\
\hline & $(-14.88)$ & $(-11.96)$ & $(-10.16)$ & $(-7.921)$ \\
\hline & {$[0.090]$} & {$[0.138]$} & {$[0.144]$} & [0.108] \\
\hline$G D P_{i t}$ & $0.694^{* * *}$ & $0.735 * * *$ & $0.722 * * *$ & $0.722^{* * *}$ \\
\hline & $(12.35)$ & $(15.08)$ & $(11.61)$ & $(11.17)$ \\
\hline$R T A_{i j t}$ & & $\begin{array}{c}0.096^{* * *} \\
(2.829)\end{array}$ & $\begin{array}{c}0.143^{* * *} \\
(3.724)\end{array}$ & \\
\hline Currency $_{i j t}$ & & $\begin{array}{c}0.192^{* * *} \\
(3.741)\end{array}$ & $\begin{array}{c}0.231^{* * * *} \\
(4.150)\end{array}$ & \\
\hline Contiguity $_{i j}$ & & $\begin{array}{c}0.563^{* * *} \\
(9.687)\end{array}$ & $\begin{array}{c}0.548^{* * *} \\
(9.085)\end{array}$ & \\
\hline Language $_{i j}$ & & $\begin{array}{c}0.319 * * * \\
(7.518)\end{array}$ & $\begin{array}{c}0.306^{* * *} \\
(7.070)\end{array}$ & \\
\hline Colony $_{i j}$ & & $\begin{array}{c}0.319^{* * *} \\
(6.089)\end{array}$ & $\begin{array}{c}0.301^{* * *} \\
(5.676)\end{array}$ & \\
\hline Distance $_{i j}$ & & $\begin{array}{c}-0.819^{* * *} \\
(-35.98)\end{array}$ & $\begin{array}{c}-0.816^{* * *} \\
(-36.16)\end{array}$ & \\
\hline$E U_{i j t}$ & & $\begin{array}{c}0.163^{* * *} \\
(3.646)\end{array}$ & & \\
\hline$R E R_{i j t-1}$ & & & & $\begin{array}{c}-0.263^{* * *} \\
(6.015)\end{array}$ \\
\hline Tarif $f_{i j k t-1}$ & & & & $\begin{array}{c}-0.0013^{* * *} \\
(-5.253)\end{array}$ \\
\hline$G D P_{i t-1}$ & & & & $\begin{array}{c}0.176^{* * *} \\
(4.458)\end{array}$ \\
\hline FE ik - jkt & Yes & Yes & Yes & Yes \\
\hline FE ij & Yes & No & No & Yes \\
\hline Observations & $63,203,049$ & $62,902,461$ & $41,139,004$ & $34,320,029$ \\
\hline R-squared & 0.640 & 0.610 & 0.616 & 0.659 \\
\hline
\end{tabular}

Notes: t-stats are in parentheses. In brackets are the standard errors, clustered at the country-pair level, and they are robust to a cluster at the exporter-importer-product level. All variables are in logarithm except for the gravity dummies $R T A_{i j t}$, Currency Cujt $_{\text {, Contiguity }}$, Colony Coj $_{\text {and }}$ for $E U_{i j t}$. All nominal variables are expressed in US dollars. Column (5) contains only the manufactured products, dropping all agricultural products. Column (6) contains less observations due to missing data in the lagged tariff variable. The level of significance is the following: $* * * \mathrm{p}<0.01,{ }^{*} \mathrm{p}<0.05,{ }^{*} \mathrm{p}<0.1$. 
"powerful" than an exchange-rate depreciation in the origin country to increase the value of bilateral exports.

\subsection{Sensitivity analysis}

In this section we study whether our results vary depending on the type of traded goods or the type of exporting countries.

\subsubsection{Goods}

The first two columns of Table 4 compare the estimation results for manufactured goods and for agricultural products, using the same specification as in the baseline. Exports in manufactured products are more responsive to a change in the real exchange rate than agricultural products, while agricultural products are more responsive to tariffs than manufactured products: a 1\% appreciation of the exporter's currency decreases manufactured (resp. agricultural) product exports by $0.48 \%$ (resp. $0.23 \%$ ), while a $1 \%$ increase in the power of the tariff decreases manufactured (resp. agricultural) exports by $1.14 \%$ (resp. 1.67\%). Unsurprisingly given the relative sample sizes, our baseline results are closer to those obtained on manufactured goods than to those based on agricultural goods.

We then use Rauch's classification (see Rauch, 1999) to distinguish between homogenous products (products whose prices are quoted on organized exchange or in trade publications) and differentiated products. Column (3) and (4) show that the impact of both real exchange rates and tariffs is slightly lower on differentiated products compared to homogenous products. Our baseline results are close to those obtained with differentiated goods.

Restricting ourselves to manufactured goods, we find that tariffs are 2.3 times more powerful than exchange rates to move exports, whereas the equivalence ratio for differentiated products is 3.2. In both cases, we are close to the range obtained for the whole sample (2.9 to 3.7$)$. 
Table 4: Trade elasticities: different types of goods

\begin{tabular}{lcccc}
\hline & & & \multicolumn{2}{c}{ Rauch classification } \\
\cline { 4 - 5 } & $(1)$ & $(2)$ & $(3)$ & $(4)$ \\
& Manuf. & Agri. & Homogenous & Differentiated \\
products & products & products & products \\
\hline \multirow{2}{*}{$R E R_{i j t}$} & $-0.479^{* * *}$ & $-0.230^{* * *}$ & $-0.492^{* * *}$ & $-0.459^{* * *}$ \\
& $(0.058)$ & $(0.035)$ & $(0.053)$ & $(0.0607)$ \\
Tarif $f_{i j k t}$ & -7.618 & -6.58 & -9.28 & -7.562 \\
& $-1.139^{* * *}$ & $-1.670^{* * *}$ & $-1.688^{* * *}$ & $-1.485^{* * *}$ \\
GDP & $(0.166)$ & $(0.076)$ & $(0.0716)$ & $(0.195)$ \\
& -10.55 & -21.98 & -23.55 & -7.609 \\
& $0.723^{* * *}$ & $0.239^{* * *}$ & $0.612^{* * *}$ & $0.783^{* * *}$ \\
& 15.07 & 6.80 & 6.832 & 12.09 \\
\hline FE ik - jkt - ij & Yes & & & \\
Observations & $54,246,572$ & $4,397,311$ & $17,510,834$ & $42,001,340$ \\
R-squared & 0.647 & 0.622 & 0.611 & 0.615 \\
\hline
\end{tabular}

Notes: t-stats are in parentheses. Standard errors are clustered at the country-pair level, and they are robust to a cluster at the exporter-importer-product level. All variables are in logarithm. All nominal variables are expressed in US dollars. The level of significance is the following: ${ }^{* * *} \mathrm{p}<0.01,{ }^{* *} \mathrm{p}<0.05,{ }^{*} \mathrm{p}<0.1$.

\subsubsection{Countries}

Table 5 studies whether trade elasticities differ for several types of countries, using the same specification as for the baseline estimations. In Column (1), we test whether the elasticity of exports to the real exchange rate differs when both the exporting and the importing countries are members of the euro area, in which case their bilateral real exchange rate only depends on inflation differentials. Specifically, we interact the real exchange rate with a dummy that is equal to unity when both $i$ and $j$ are members of the euro area. The resulting coefficient is significantly positive. Combining it with the non-interacted coefficient on the real exchange rate (which remains unaffected), we find that the reaction of exports to the bilateral real exchange rate is more than halved when the two countries are part of the euro area. This striking result does arise from membership of the single market, as evidenced by Column (2) which interacts the real exchange rate with a dummy that is equal to unity when both $i$ 
and $j$ are members of the European union, and finds an insignificant coefficient. ${ }^{32}$ Hence the lower coefficient found on the real exchange rate for intra-European trade is related to the fixed nominal rate rather than to economic integration. The non-interacted coefficient stays unaffected, which confirms that it can be used to study the impact of exchange rate policies on exports.

In Column (3), we study whether trade elasticities differ for advanced economies. Specifically, we interact the real exchange rate and the tariff with a dummy that is equal to unity when both $i$ and $j$ are OECD members. The elasticity of exports to the real exchange rate is found to be reduced for OECD countries, whereas the elasticity to tariffs is magnified.

Finally, Column (4) reports the results obtained when interacting tariffs and real exchange rates with a dummy for large countries. ${ }^{33}$ It may be argued that trade between large economies reacts more to the exchange rate or to tariffs because these countries are less likely to adjust their margins. We find an insignificant coefficient on the interacted dummy with the real exchange rate, but a highly significant, negative coefficient on the interacted dummy with the tariff. On the whole, restricting the analysis to large countries inflates the "'equivalence"' between tariffs and exchange rates from 2.9 in our baseline estimation to 4.2 here.

\subsection{Non-linearities}

As shown in Figure 2 in the data section, a tariff cut is more permanent on average than a tariff hike. Hence a cut may have more impact on trade than a hike. This possibility is explored in Table 6, Column (1), where the tariff is interacted with a dummy that is equal to unity when the tariff has increased relative to the previous year. The tariff in the destination country has significantly less negative impact on exports just after an increase than when it is either constant or declining: a $1 \%$ tariff increase in the destination country reduces exports by $0.98 \%$, while a $1 \%$ tariff cut stimulates exports by $1.44 \%$. Hence, the equivalence ratio between tariffs and the real exchange rate is 3.4 for a tariff cut but only 2.3 for a tariff increase.

\footnotetext{
${ }^{32}$ We do not repeat the same exercise for tariffs since they are equal to zero within the EU and within the euro area.

${ }^{33}$ This country group comprises the United States, Canada, France, Germany, United Kingdom, Japan, Italy, Mexico, Turkey, South Korea and Spain.
} 
Table 5: Trade elasticities: different types of countries

\begin{tabular}{|c|c|c|c|c|}
\hline & $\begin{array}{c}(1) \\
\text { Euro } \\
\text { area }\end{array}$ & $\begin{array}{c}(2) \\
\text { European } \\
\text { Union }\end{array}$ & $\begin{array}{c}(3) \\
\text { OECD } \\
\text { countries }\end{array}$ & $\begin{array}{c}(4) \\
\text { Large } \\
\text { economies }\end{array}$ \\
\hline$R E R_{i j t}$ & $\begin{array}{c}-0.477^{* * *} \\
(-8.072)\end{array}$ & $\begin{array}{c}-0.475^{* * *} \\
(-8.063)\end{array}$ & $\begin{array}{c}-0.491 * * * \\
(-8.323)\end{array}$ & $\begin{array}{c}-0.480 * * * \\
(-8.12)\end{array}$ \\
\hline$T A R I F F_{i j k t}$ & $\begin{array}{c}-1.369 * * * \\
(-14.90)\end{array}$ & $\begin{array}{c}-1.365^{* * *} \\
(-14.88)\end{array}$ & $\begin{array}{c}-1.072^{* * *} \\
(-11.18)\end{array}$ & $\begin{array}{c}-1.285^{* * * *} \\
(-14.00)\end{array}$ \\
\hline$G D P_{i t}$ & $\begin{array}{c}0.695^{* * *} \\
(12.37)\end{array}$ & $\begin{array}{c}0.694^{* * * *} \\
(12.35)\end{array}$ & $\begin{array}{c}0.704^{* * *} \\
(12.55)\end{array}$ & $\begin{array}{c}0.696^{* * *} \\
(12.38\end{array}$ \\
\hline$R E R_{i j t} * E A_{i j t}$ & $\begin{array}{c}0.262^{* * *} \\
(2.653)\end{array}$ & & & \\
\hline$R E R_{i j t} * E U_{i j t}$ & & $\begin{array}{c}-0.00551 \\
(-0.633)\end{array}$ & & \\
\hline$R E R_{i j t} * O E C D_{i j t}$ & & & $\begin{array}{c}0.0257^{* * *} \\
(3.900)\end{array}$ & \\
\hline$T A R I F F_{i j k t} * O E C D_{i j t}$ & & & $\begin{array}{c}-0.907 * * * \\
(-6.722)\end{array}$ & \\
\hline$R E R_{i j t} * \operatorname{Large}_{i j t}$ & & & & $\begin{array}{l}-0.063 \\
(-0.90)\end{array}$ \\
\hline$T_{A R I F F_{i j k t}} * \operatorname{Large}_{i j t}$ & & & & $\begin{array}{c}-0.737 * * * \\
(-3.24)\end{array}$ \\
\hline FE ik - jkt - ij & Yes & Yes & Yes & Yes \\
\hline Observations & $63,203,049$ & $63,203,049$ & $63,203,049$ & $63,203,049$ \\
\hline R-squared & 0.640 & 0.640 & 0.640 & 0.640 \\
\hline
\end{tabular}

Notes: standard errors are clustered at the country-pair level, t-stats are in parentheses. All variables are in logarithm except for the inflation; ; all nominal variables are expressed in US dollars. The level of significance is the following: ${ }^{* * *} \mathrm{p}<0.01,{ }^{* *} \mathrm{p}<0.05,{ }^{*} \mathrm{p}<0.1$ 
Now, it may be argued that tariffs in the destination country have more impact on exports when the exporter's currency is overvalued or, symmetrically, that the overvaluation of the exporter's currency is more detrimental to exports when tariffs in the destination are high. Column (2) shows that this is indeed the case: the coefficient on the real exchange rate interacted with the tariff is significantly negative. Trade and monetary barriers tend to reinforce each other.

Next, we also test whether the real exchange rate has more impact on exports when it appreciates than when it depreciates by interacting the real exchange rate with a dummy equal to unity when the real exchange rate has depreciated relative to the previous year. The results reported in Column (3) show that, although significant, the interacted term bears a very small coefficient. The almost symmetric reaction of exports to exchange-rate appreciations or depreciations is consistent with the pattern shown in Figure 3 (contrasting with tariffs).

Column (4) explores whether the real exchange rate has more impact on exports when it is "misaligned", i.e. far away from its trend. For each bilateral real exchange rate, we calculate the deviation of the log-exchange rate from a linear trend. The real exchange is then interacted with the square of this deviation, called "misalignment". The interacted term has significant, negative effect on exports, confirming that large deviations have more impact than small ones. However the coefficient on the (non-interacted) real exchange rate remains close to its baseline value. ${ }^{34}$

\subsection{Wrap-up}

From our econometric estimations, we can draw the following conclusions: (i) as a general rule, tariffs have around 2.9 times more impact on exports than the real exchange rate; (ii) the equivalence ratio is slightly smaller (2.4) for manufactured goods and higher (3.2) for differentiated products; (iii) it is larger (4.2) for trade between large countries; (iv) the equivalence ratio is smaller for a tariff hike (2.3) than for a tariff cut (3.4), whereas it is

\footnotetext{
${ }^{34}$ The same exercise is not possible for tariffs due to the limited number of tariff changes at the exporterimporter-product level.
} 
Table 6: Non-linear estimations

\begin{tabular}{|c|c|c|c|c|}
\hline & \multicolumn{4}{|c|}{ Dep. var. : Exports ${ }_{i j k t}$} \\
\hline & (1) & $(2)$ & $(3)$ & $(4)$ \\
\hline$R E R_{i j t}$ & $\begin{array}{c}-0.428^{* * *} \\
(-6.773)\end{array}$ & $\begin{array}{c}-0.401^{* * *} \\
(-7.333)\end{array}$ & $\begin{array}{c}-0.405^{* * *} \\
(-7.406)\end{array}$ & $\begin{array}{c}-0.393^{* * *} \\
(-7.204)\end{array}$ \\
\hline Tarif $f_{i j k t}$ & $\begin{array}{c}-1.440^{* * *} \\
(-11.44)\end{array}$ & $\begin{array}{c}-1.743^{* * *} \\
(-12.68)\end{array}$ & $\begin{array}{c}-1.680^{* * *} \\
(-12.18)\end{array}$ & $\begin{array}{c}-1.677^{* * *} \\
(-12.18)\end{array}$ \\
\hline Tarif $f_{i j k t} *$ Increase & $\begin{array}{c}0.461^{* * *} \\
(6.182)\end{array}$ & & & \\
\hline$R E R_{i j t} *$ Tariff $f_{i j k t}$ & & $\begin{array}{c}-0.150 * * * \\
(5.366)\end{array}$ & & \\
\hline$R E R_{i j t} *$ Depreciation & & & $\begin{array}{c}-0.00428^{* *} \\
(2.536)\end{array}$ & \\
\hline$R E R_{i j t} *$ Misalignment & & & & $\begin{array}{c}-0.078^{* * *} \\
(3.866)\end{array}$ \\
\hline Controls & Yes & Yes & Yes & Yes \\
\hline FE ik-jkt & Yes & Yes & Yes & Yes \\
\hline Observations & $44,222,566$ & $63,142,608$ & $63,142,608$ & $63,142,608$ \\
\hline R-squared & 0.630 & 0.609 & 0.609 & 0.609 \\
\hline
\end{tabular}

Notes: t-stats are in parentheses. Standard errors are clustered at the country-pair level, and they are robust to a cluster at the exporter-importer-product level. All variables are in logarithm except for the gravity dummies $R T A_{i j t}$, Currency ${ }_{i j t}$, Contiguity $_{i j}, C_{\text {olony }}$ ij and for $E U_{i j t}$. All nominal variables are expressed in US dollars. Column (1) contains less observations due to missing data in the tariff variable when computing its year-on-year variation. Column (4) and (5) contain less observations due to missing data in the quantity of exports variable. The level of significance is the following: ${ }^{* * *} \mathrm{p}<0.01,{ }^{* *} \mathrm{p}<0.05,{ }^{*} \mathrm{p}<0.1$. 
symmetric whether the real exchange rate appreciates or depreciates; and $(\mathrm{v})$ the exchange rate has more impact on trade when it is misaligned and when it interacts with relatively high tariffs.

In the following, we set to 3 the baseline equivalence ratio between tariffs and the exchange rate, and subsequently produce sensitivity analysis for the equivalence going from 1 to 4 .

\section{A stylized model of trade and currency "wars"}

Here we study the implications of our estimated equivalence ratios for the reaction of a government ${ }^{35}$ to a demand shock, based on a simple, static model adapted from Blanchard (2017). The government is supposed to have an internal objective (GDP equal to its potential level) and an external one (a certain level of trade balance which we set to zero for simplicity). The relative weight of the latter objective is labelled $\theta$.

Why could a government have an external objective on top of the stabilization of domestic activity? First, the government may have an inter-temporal motivation: an external deficit today will have to be paid back tomorrow or by the next generation. This is fine if population and GDP are growing, but an ageing economy may aim at a trade surplus today in order to pay for future pensions. Another reason for having an external objective is the existence of financial constraints. If external debt is already high in percent of GDP, additional borrowing may trigger a downgrading and/or an increase in interest rates. Finally, a government may consider a trade deficit as a progressive empoverishment of the residents and oppose the corresponding capital inflows (that will sometimes involve cross-border take-overs).

There may be two policy instruments (trade and monetary), in which case both objectives can be reached simultaneously; or only one instrument (either trade or monetary), in which case a trade-off needs to be made between internal and external equilibrium. In our short-term setting, an import tariff or a depreciated currency both have a positive impact on the trade balance, but they also reduce households' purchasing power. We compare the optimal policy

\footnotetext{
${ }^{35}$ We use the term "government" in an extensive way that also incorporates the central bank. We do not discuss the coordination problems between the government (which decides on trade policy) and the central bank (which decides on monetary policy).
} 
(the one that minimizes the government's loss function) depending on the relative impact of tariffs and of the exchange rate on trade flows, and on the internal channel of monetary policy. Then, we extend the analysis to a two country, non-cooperative setting where each government considers the other one's policy as given. We analyse the incentive of each government to use tariffs or monetary policy to stabilize domestic and/or foreign net demand after a negative demand shock.

\subsection{The model}

We first consider an open economy in isolation, before moving to a two-country setting. The starting point is the following identity:

$$
Y=C+I+\frac{E B}{P}
$$

where $Y, C$ and $I$ denote GDP, consumption and investment, respectively, all expressed in units of domestic good, $B$ is the trade balance expressed in units of foreign currency, $E$ is the nominal exchange rate (units of domestic currency per unit of foreign currency) and $P$ is the GDP deflator.

The volume of consumption $C$ is assumed to be a fixed share $c \in[0,1]$ of the purchasing

power of domestic income: $C=c \frac{P Y}{P_{c}}$, where $P_{c}$ is the consumer price index. The latter is a weighted average of the price of domestically-produced goods $P$ and of imported goods. Assuming a pass-through coefficient of $\pi$ for both the exchange rate and the import tariffs (which we have shown to be similar), the consumer price index is:

$$
P_{c}=P^{1-\eta}\left(P^{*}\right)^{\eta}(E(1+\tau))^{\pi \eta},
$$

with $P^{*}$ the price of the foreign good (in foreign currency), $\tau$ the import tariff and $\eta \in[0,1]$ the share of the foreign good in the consumption basket. As for the volume of investment $I$, it is assumed to react to the interest rate $r$ with an elasticity $\alpha>0: I_{0}(1+r)^{-\alpha}$, where $I_{0}>0$ is a constant. 
Since we are interested in the short-term equilibrium, we assume the price of both the domestic and the foreign goods to be fixed: $P=P^{*}=1$. Equation (4) becomes:

$$
Y=c Y[E(1+\tau)]^{-\pi \eta}+I_{0}(1+r)^{-\alpha}+E B
$$

The first term embodies the negative impact of a weaker currency (higher exchange rate $E$ ) or an import tariff $\tau$ on aggregate demand through reduced purchasing power. The second term shows the positive impact of a lower interest rate on aggregate demand (internal channel of monetary policy). The third one represents net external demand. We write the trade balance $B$ as the difference between the value of exports and that of imports, both being expressed in foreign currency. With $P=P^{*}=1$, we have:

$$
B=X_{0} E^{\epsilon}\left(1+\tau^{*}\right)^{-\zeta \epsilon} Y^{* \gamma^{*}}-M_{0} E^{-\epsilon}(1+\tau)^{-\zeta \epsilon} Y^{\gamma}
$$

where $\tau^{*}$ and $Y^{*}$ represent the foreign import tariff and foreign GDP, respectively (both exogenous), $\gamma, \gamma^{*}>0$ are the home and foreign income elasticities of imports, $\epsilon>0$ is the elasticity of exports to the exchange rate, and $\zeta>0$ is a multiplier applied to this elasticity to get the elasticity of imports to the tariff. Finally, $X_{0}>0$ and $M_{0}>0$ are constant.

The exchange rate is assumed to be linked to the interest rate through the uncovered interest parity, with an exogenous foreign interest rate $r^{*}$ :

$$
E=\left(\frac{1+r^{*}}{1+r}\right)^{\delta}
$$

where $\delta>0$ measures the expected persistence of the interest differential (there are no explicit expectations in this simple, static model).

Equations (6) and (7) can be linearized around the internal and external equilibria, and around $E=1, r=0$ and $\tau=0$. With $y=d Y / Y, y^{*}=d Y^{*} / Y^{*}, e=d E / E$ and $b=d B / Y$, assuming $\delta=1$ and denoting by $u$ and $v$ exogenous shocks, we get (see Appendix B): 


$$
\begin{gathered}
y=\frac{1}{1-c+\phi \gamma}\left[-(2 \epsilon \phi-\pi \eta c+(1-c+\phi \gamma) \mu) r+(\phi \zeta \epsilon-\pi \eta c) \tau+\phi\left(\gamma y^{*}-\zeta \epsilon \tau^{*}\right)+v+u\right] \\
b=\phi\left(\zeta \epsilon\left(\tau-\tau^{*}\right)+2 \epsilon \delta\left(r^{*}-r\right)+\gamma\left(y^{*}-y\right)\right)+v
\end{gathered}
$$

where $\mu=\frac{\alpha I_{0}}{Y(1-c+\phi \gamma)}>0$ and $\phi=\frac{X}{Y}>0$.

Following Blanchard (2017), we finally assume that the government has two objectives: internal equilibrium (GDP equal to its potential level, e.g. a zero output gap), and external equilibrium (a trade balance equal to zero). ${ }^{36}$ The government's programme is the following:

$$
\underset{r, \tau}{\operatorname{MinL}}=\frac{1}{2}\left(y^{2}+\theta b^{2}\right)
$$

The government has two policy instruments: the interest rate and the import tariff. The interest rate has an ambiguous effect on domestic output: on the one hand, a rate cut stimulates investment and (through the involved currency depreciation) raises net exports; on the other hand, the depreciation reduces the purchasing power of the consumers. The tariff also has ambiguous effect on output since it stimulates net exports but reduces households' purchasing power. We expect an interest-rate cut or an increase in the import tariff to have a positive net impact on output in the short run if the purchasing power effect is less than the other effects.

\subsection{Calibration}

We calibrate our model to fit the US economy. Using the World Bank Development Indicators for the year 2015, we recover the consumption share $c=0.7$ and the ratio of trade in goods to GDP $X / Y$ which gives $\phi=0.1$. We also recover the share of the imported good in the consumption basket, hence $\eta=0.2$, from Hale and Hobijn (2016) .

Based on our own estimations of the elasticities of trade to the exchange rate and to the

\footnotetext{
${ }^{36}$ Alternatively, the government may target any positive or negative level of trade balance, which will not affect our results.
} 
import tariff, we set $\epsilon=0.5, \zeta=3$, and $\pi=0.6$. We also found an income elasticity of exports varying between 0.45 and 0.7 . We choose the median value, and set $\gamma=0.6$. Like Blanchard (2017), we assume $\delta=1$, i.e. an interest-rate variation is expected to last one year.

We calibrate $\mu$ based on the literature on the impact of a rate cut on US output (see Appendix B). Using a DSGE model for the period from 1988 to 2013, Brayton et al. (2014) find the short-term response of output to a 1 percentage point fall in the US policy rate to be comprised between +0.1 and +0.4 percent. Focusing on the 1984-2008 period, Boivin et al. (2010) find that a rate cut by 1 pp increases output by $0.2 \%$ in the short run. We select the medium figure of 0.3 which, given the other parameters, leads to $\mu=0.3$.

Finally, we assume that the internal and external objectives of the government bear equal weights, hence $\theta=1$, while subsequently studying how our results react to different values of $\theta$.

With this calibration, a 1 pp. cut in the interest rate increases the trade balance by $0.08 \%$ of GDP and output by $0.34 \%$. Likewise, a 1 pp. increase in import tariffs increases the trade balance by $0.14 \%$ and ouput by $0.18 \%$ despite the negative impact on purchasing power. ${ }^{37}$ Although the tariff is more "powerful" than an exchange-rate depreciation to reduce imports, the internal channel of monetary policy contributes to the stabilizing impact of an interest-rate cut.

These effects depend on two specific parameters: $\zeta$, the compared impact of the tariff relative to the exchange rate on trade, and $\mu$, the investment (or internal) channel of monetary policy. The positive impact of a tariff hike on both output and the trade balance is increasing in $\zeta$, while the impact of monetary policy is independent from this parameter; ${ }^{38}$ in turn, a cut in interest rate induces a larger increase in output, thus inducing a lower increase in the trade balance when $\mu$ is large, whereas the impact of trade policy does not depend on $\mu .^{39}$

\footnotetext{
${ }^{37}$ The calibration gives the following partial derivatives: $\frac{\partial y}{\partial r}=-0.34, \frac{\partial y}{\partial \tau}=0.18, \frac{\partial b}{\partial r}=-0.08$ and $\frac{\partial b}{\partial \tau}=0.14$.

${ }^{38}$ The partial derivatives as a function of $\zeta$ are the following (when all the other parameters are set at their reference values): $\frac{\partial y}{\partial r}=-0.34, \frac{\partial y}{\partial \tau}=\frac{5 \zeta}{36}-\frac{7}{30}, \frac{\partial b}{\partial r}=-0.08$ and $\frac{\partial b}{\partial \tau}=\frac{\zeta}{24}+\frac{7}{500}$.

${ }^{39}$ The partial derivatives as a function of $\mu$ are the following (when all the other parameters are set at their reference values): $\frac{\partial y}{\partial r}=-\frac{2}{45}-\mu, \frac{\partial y}{\partial \tau}=0.18, \frac{\partial b}{\partial r}=\frac{3 \mu}{50}-\frac{73}{750}$ and $\frac{\partial b}{\partial \tau}=0.14$.
} 


\subsection{Trade or monetary policy?}

Here we simulate the reaction of the government to a negative demand shock when only one policy instrument (trade or monetary) is available, or when both instruments are available.

Table 7 shows the optimal policy response to a negative domestic demand shock of 1 percent. When only trade policy is available (for instance, if monetary policy is constrained by the zero lower bound, or if the country does not have an independent currency), the government reacts by increasing the tariff, which deteriorates consumers' purchasing power, but at the same time increases the trade balance. Ex post, output is partially stabilized. However the trade balance increases since the higher tariff adds to the impact of lower domestic demand to reduce imports.

With only monetary policy available (for instance, due to trade agreements or WTO constraints), the government cuts the interest rate, which stabilizes output both through the internal and the external channels. However this raises the trade balance. Ex post, output is partially stabilized and the trade balance increases. The residual loss (last column of Table 7) is smaller when the government reacts with monetary policy as when it relies on trade policy: monetary policy is more stabilizing.

When both policy instruments are available, it is optimal to react to the domestic demand shock by cutting the interest rate and at the same time reducing the import tariff in order to compensate for the detrimental impact of the currency depreciation on consumers' purchasing power. Both objectives (internal and external equilibrium) are reached since there are two independent instruments.

The case of a negative trade shock of one percent is presented in Table 8 . When there is only one instrument available, the government responses are similar qualitatively as for the domestic demand shock. Again, monetary policy is more stabilizing than trade policy. With

two policy instruments, though, the response is different: now the government simultaneously cuts the interest rate and raises the import tariff. Both measures weigh negatively on domestic consumption, but this is compensated by the internal channel of monetary policy.

Our results confirm that import tariffs and monetary policy are partly substitutes in the 
Table 7: Policy reaction to a negative domestic demand shock $u=-1 \%$

\begin{tabular}{lccccc}
\hline & $\tau$ & $r$ & $b$ & $y$ & $L$ \\
\cline { 2 - 6 } One instrument: $\tau$ & 0.0918 & 0 & 0.0144 & -0.01069 & 0.0002 \\
One instrument: $r$ & 0 & -0.0755 & 0.0077 & -0.0018 & 0.00003 \\
Two instruments: $\tau, r$ & -0.0833 & -0.1250 & 0 & 0 & 0 \\
\hline
\end{tabular}

Note: the table reports deviations from baseline.

Source: model simulations.

Table 8: Policy reaction to a negative external shock $v=-1 \%$

\begin{tabular}{lccccc}
\hline & $\tau$ & $r$ & $b$ & $y$ & $L$ \\
\cline { 2 - 6 } One instrument: $\tau$ & 0.1181 & 0 & 0.0081 & -0.0061 & 0.00005 \\
One instrument: $r$ & 0 & -0.0819 & -0.0018 & 0.0004 & 0.000002 \\
Two instruments: $\tau, r$ & 0.0200 & -0.0700 & 0 & 0 & 0 \\
\hline
\end{tabular}

Note: the table reports deviations from baseline.

Source: model simulations.

short term, consistent with the empirical findings of Eichengreen and Irwin (2010) for the interwar period. However, trade policy is clearly a second best compared to monetary policy.

When both instruments are available, they are combined differently depending on whether the shock is domestic or foreign. In both cases, the government cuts the interest rate in reaction to a negative shock. Monetary policy is accompanied by a cut in the import tariff in case of a domestic shock, but a rise in case of a foreign shock.

Figure 4 in Appendix $\mathrm{C}$ plots the optimal reaction of the tariff to a negative demand shock depending on the equivalence ratio, $\zeta$, when only trade policy is available. For $\zeta$ higher than about 1.5, the optimal response is an increase in the tariff, with relatively stable results from 2.9 (our baseline estimate) to 4 (for trade between large economies). However, for $\zeta<1.5$, it is optimal for the government to lower the tariff since the impact of a higher tariff on output becomes negative: the positive impact through higher net exports is less than the negative impact through reduced purchasing power.

We now turn to the role played by the internal channel of monetary policy, represented by $\mu$. In Figure 5 (Appendix C), we plot the optimal monetary response to a negative demand shock depending on this parameter. For $\mu=0$ to 0.4 , the optimal reaction to a negative shock is always a cut in the interest rate, although with different magnitudes. 
This first group of results suggests that, with our calibration, the optimal reaction to a negative demand shock is to lower the interest rate (and depreciate the currency), whether or not trade policy is available. Reacting to the shock through increasing the import tariff is less stabilizing for output. If $\zeta$ is much smaller than in our calibration, it becomes optimal to react to a negative demand shock by lowering rather than increasing the tariff. Based on these results, it seems that there is more scope for a "currency war" than for a "trade war". However it is mostly a question of instrument availability: when monetary policy is constrained, trade policy can act as an imperfect substitute, and vice-versa.

\subsection{Policy mix}

Tables 7 and 8 show that, when both trade and monetary policy are available, the government will react to a negative demand shock by lowering the interest rate and increasing or decreasing the import tariff (depending on the nature of the shock). Table 9 explores the robustness of these result with respect to the equivalence ratio $\zeta$. It turns out that whatever $\zeta$, the combined reaction of monetary and trade policy is qualitatively the same. A higher $\zeta$ just implies a lower reaction of both instruments, since trade policy becomes more powerful.

Table 10 looks at the optimal policy-mix for different values of $\mu$. For $\mu>0$, the optimal response to a negative demand shock is always a cut in the interest rate, in combination with a cut in the import tariff (domestic shock) or of either an increase or a cut in the import tariff (external shock). The higher the internal channel of monetary policy $(\mu)$, the more limited the cut in the interest rate (since a smaller cut becomes sufficient to stabilize aggregate demand), but the more likely the government will increase the import tariff.

Conversely, if $\mu=0$, the internal channel of monetary policy is muted, so it is no longer optimal to cut the interest rate. The stabilization of the economy then goes through an increase in the import tariff and, simultaneously, an increase in the interest rate (and an apreciation of the currency) to compensate the negative impact of the tariff on domestic consumption. Interestingly, the government's response is similar for both types of shocks.

We conclude that, when both instruments are available, the reaction to a negative demand 
Table 9: Policy-mix depending on $\zeta$

\begin{tabular}{lcc}
\hline & $\tau$ & $r$ \\
\cline { 2 - 3 } Domestic shock $u=-1 \%$ & & \\
$\zeta=1$ & -0.1042 & -0.0521 \\
$\zeta=2$ & -0.0926 & -0.0926 \\
$\zeta=3$ & -0.0833 & -0.1250 \\
$\zeta=4$ & -0.0758 & -0.1515 \\
& & \\
External shock $v=-1 \%$ & & \\
$\zeta=1$ & 0.0250 & -0.0875 \\
$\zeta=2$ & 0.0222 & -0.0778 \\
$\zeta=3$ & 0.0200 & -0.0700 \\
$\zeta=4$ & 0.0182 & -0.0636 \\
\hline
\end{tabular}

Note: the table reports deviations from baseline.

Source: model simulations.

shock is normally an expansionary monetary policy, except when the internal transmission channel is muted (at the zero lower bound), where it becomes optimal to react through an increase in the import tariff rather than through a monetary expansion. In turn, the reaction of trade policy is normally to accompany the loosening of monetary policy by reducing the import tariff. However, when the cut in the interest rate is limited due to a powerful internal transmision channel (high $\mu$ ), the exchange-rate depreciation is no longer sufficient to absorb an external shock. In that case, the cut in the interest rate is accompanied with an increase in the import tariff.

\subsection{Weighing external and internal objectives}

Table 11 shows how the policy reaction to a negative demand shock varies depending on $\theta$, the weight of the trade balance in the government's loss function. Here we restrict the analysis to a single policy instrument. ${ }^{40}$

In our baseline simulations, we have set $\theta=1$. If $\theta=0$, then the government only has an internal objective, whereas if $\theta=1000$, the government mainly cares the external balance.

\footnotetext{
${ }^{40}$ For $\theta=0$ or $\theta \rightarrow \infty$, there is only one objective which can be reached with a single instrument. For intermediate values of $\theta$, there are two objectives and two instruments, hence the two objectives are reached the same way whatever $\theta$.
} 
Table 10: Policy-mix depending on $\mu$

\begin{tabular}{lcc}
\hline & \multicolumn{1}{c}{$\tau$} \\
\cline { 2 - 3 } Domestic shock $u=-1 \%$ & & \\
$\mu=0$ & & \\
$\mu=0.1$ & -0.2381 & 0.3571 \\
$\mu=0.2$ & -0.1515 & -0.2273 \\
$\mu=0.3$ & -0.0833 & -0.1250 \\
$\mu=0.4$ & -0.0575 & -0.0862 \\
& & \\
External shock $v=-1 \%$ & & \\
$\mu=0$ & 0.2000 & 0.2000 \\
$\mu=0.1$ & -0.4000 & -0.7000 \\
$\mu=0.2$ & -0.0182 & -0.1273 \\
$\mu=0.3$ & 0.0200 & -0.0700 \\
$\mu=0.4$ & 0.0345 & -0.0483 \\
\hline
\end{tabular}

Note: the table reports deviations from baseline.

Source: model simulations.

We first consider a negative shock to domestic demand. Remember that such shock reduces domestic output but increases the trade balance, and that cutting the interest rate leads the trade balance to increase even further. If $\theta$ is small, the government disregards the impact of the shock and of the policy response on the trade balance, which leads to a strong reaction through either monetary easing or a tariff hike. Conversely, if $\theta=1000$, the government disregards the output gap. What is important is to stabilize the trade balance, through an increase in the interest rate (and an exchange-rate appreciation) or through a cut in the import tariff.

Following a negative external demand shock, both the output gap and the trade balance decline, and a cut in the interest rate or an increase in the import tariff are stabilizing for both variables. Hence, whatever the value of $\theta$, it is always optimal to increase the tariff or cut the interest rate. A greater weight on the trade balance will induce more rate cut and less tariff hike. This is because the interest rate is relatively less powerful than the import tariff to stabilize the trade balance, and relatively more powerful to stabilize the output gap.

This final set of results suggests that beggar-thy-neighbor policies are almost always optimal after a negative demand shock. The only exception is for a government seeking to 
Table 11: Policy reaction to a negative demand shock, depending on $\theta$ (one instrument)

\begin{tabular}{lc||c}
\hline & \multicolumn{1}{c||}{$\tau$} & $r$ \\
\cline { 2 - 3 } Domestic shock $u=-1 \%$ & & \\
$\theta=0$ & 0.1515 & -0.0806 \\
$\theta=1$ & 0.0918 & -0.0755 \\
$\theta=10$ & 0.0122 & -0.0454 \\
$\theta=100$ & -0.0092 & 0.0049 \\
$\theta=1000$ & -0.0117 & 0.0191 \\
& & \\
External shock $v=-1 \%$ & \\
$\theta=0$ & 0.1515 & -0.0806 \\
$\theta=1$ & 0.1181 & -0.0819 \\
$\theta=10$ & 0.0735 & -0.0891 \\
$\theta=100$ & 0.0615 & -0.1012 \\
$\theta=1000$ & 0.0601 & -0.1046 \\
\hline
\end{tabular}

Note: the table reports deviations from baseline.

Source: model simulations.

stabilize the trade balance after a domestic demand shock, in which case a depreciation or a tariff hike will not help.

\subsection{A two-country extension}

We now come back to our baseline calibration and turn to a two-country model where Home and Foreign are symmetric economies. We consider a non-cooperative setting where each government tries to stabilize national output and the trade balance. They both react to a common shock using either the interest rate or the import tariff, considering the policy of the other government as given (Nash equilibrium). When both countries have two instruments available, the model is overidentified ${ }^{41}$ therefore we only consider the cases where one instrument is available in each country.

Although foreign policy instruments are considered exogenous to the home government, the foreign economy itself (represented by $y^{*}$ and $b^{*}$ ) is not: when cutting the home interest rate, the home government knows that doing so will affect foreign output, which will in turn

\footnotetext{
${ }^{41}$ Stabilizing the trade balance of the home country automatically stabilizes the trade balance of the foreign economy.
} 
Table 12: Nash equilibria: negative demand shock

\begin{tabular}{lccccc}
\hline & $\tau, \tau^{*}$ & $r, r^{*}$ & $b, b^{*}$ & $y, y^{*}$ & $L, L^{*}$ \\
\cline { 2 - 6 } Domestic shock $u=u^{*}=-1 \%$ & -0.1190 & 0 & 0 & 0 & 0 \\
One instrument: $\tau, \tau^{*}$ & 0 & -0.0926 & 0 & 0 & 0 \\
One instrument: $r, r^{*}$ & & & & & \\
\hline External shock $v=v^{*}=-1 \%$ & -0.1554 & 0 & -0.01 & 0.0102 & 0.0001 \\
One instrument: $\tau, \tau^{*}$ & 0 & -0.0990 & -0.01 & 0.0023 & 0.00005 \\
One instrument: $r, r^{*}$ & & & & & \\
\hline
\end{tabular}

Note: the table reports deviations from baseline.

Source: model simulations.

affect home exports. Thus, an additional, indirect channel of policy transmission is now at play.

Suppose for instance that the home government cuts the home interest rate. This decision will have a positive impact on home output and on the home trade balance through the combination of the domestic transmission channel (higher investment) and the external channel (currency depreciation increasing competitiveness but reducing purchasing power). Now, there is also an indirect channel that goes through foreign output. Since the foreign currency appreciates but the foreign interest rate does not increase (Nash hypothesis), foreign output is in fact expected to increase following the shock, thanks to higher purchasing power. Hence, the home government expects its interest-rate cut to have more positive impact on home exports and output, compared to the small open economy case.

In turn, if the home government increases its import tariff, it can expect a fall in foreign output, hence reduced impact on home exports and output. As shown in Table 12, it is now optimal to react to a negative demand shock by cutting the import tariff rather than increasing it: the tariff cut stimulates home purchasing power with little impact through the combined direct and indirect external channels. ${ }^{42}$

Because the demand shock is symmetric and hits two symmetric economies, the reactions are the same. A common negative demand shock $\left(u=u^{*}=-1 \%\right)$ decreases both outputs but leaves the trade balances unaffected. Both government can thus stabilize their output

\footnotetext{
${ }^{42}$ In the two country setting, we have the following partial derivatives for the Home economy: $\frac{\partial y}{\partial r}=-0.21$, $\frac{\partial y}{\partial \tau}=-0.04, \frac{\partial b}{\partial r}=-0.1$ and $\frac{\partial b}{\partial \tau}=0.15$.
} 
by either cutting the tariff (to regain purchasing power) or by decreasing the interest rate to boost investment. Whatever the instrument, output is fully stabilized in both countries (see Table 12).

When facing a negative trade shock $\left(v=v^{*}=-1 \%\right)$, the trade balances cannot be stabilized, because the symmetric reactions in tariff or interest rate cancel each other. Both countries choose to decrease the tariff or the interest rate to try to stabilize their output, just as for a negative shock on domestic demand. Comparing the losses in the last column of Table 12 suggests that a monetary response is much more stabilizing than a trade policy.

Hence, the results obtained in the small-economy case are confirmed in the two-country model: with our calibration, monetary policy appears more appropriate than trade policy to stabilize the economy after a demand shock. The risk of a trade war is now also limited by the fact that each country anticipates the negative impact of a tariff on its own exports, even without anticipating any form of trade retaliation.

\section{Conclusion}

Recent decades have witnessed a proliferation of bilateral and regional trade agreements on the top of more and more countries being part of the World Trade Organization. This evolution has constrained the protectionist response to shocks: unlike during the Great depression of 1929, the Great recession of 2009 has generally not been accompanied with a revival of protectionism, although some tariff hikes have been observed. International disputes have then moved to the monetary sphere, with some countries being accused of leading a "currency war".

In this paper, we compare the elasticity of exports to tariffs and to the exchange rate, based on a panel of HS6-level bilateral trade flows for 110 countries over 1989-2013. For the whole sample, we find that a 1 percent depreciation of the exporter country's currency has the same impact as a cut in the importer's tariff by $0.34 \%$ : a tariff cut in the destination

country is 2.9 times more "powerful" than an exchange-rate depreciation in the origin country to increase the value of exports. This order of magnitude is shown to be relatively robust, 
although we evidence some sensitivity depending on the types of products and of countries, and a few non-linearities.

We then incorporate our baseline result into a simple open economy model where policymakers target both internal and external balance. We find that, if both trade and monetary "weapons" are available, the government reacts to a negative demand shock by cutting the home interest rate (and letting the home currency depreciate) while the accompanying trade policy depends on the nature of the shock and on the intensity of the internal transmision channel of monetary policy. If only one policy instrument is available, the government may either cut the interest rate or increase the import tariff. However, increasing the import tariff is less effective in stabilizing output, and in a two-country setting it is optimal to rather cut the import tariff. One implication of our results is that, in normal times the home country will more likely react to a trade aggression through monetary easing rather than through retaliating on trade policy. At the ZLB, though it can be optimal to react to a trade (or monetary) "aggression" through trade retaliation.

Our results confirm previous research showing that the incentive to carry out non-cooperative policies increases at the zero lower bound, when the internal transmission channel of monetary policy is muted. However, we show that such non-cooperative policy is more likely to go through a trade policy rather than a currency devaluation: it becomes optimal to react to a negative demand shock by increasing the import tariff while allowing the home currency to appreciate in order to compensate the negative impact of the tariff on home purchasing power. 


\section{References}

Anderson, J. E. (1979). "A Theoretical Foundation for the Gravity Equation." The American Economic Review, 69(1), 106-116.

Anderson, J. E., Vesselovsky, M., and Yotov, Y. V. (2013). "Gravity, Scale and Exchange Rates." NBER Working Paper 18807, National Bureau of Economic Research, Inc.

Anderson, J. E., and Wincoop, E. v. (2003). "Gravity with Gravitas: A Solution to the Border Puzzle." American Economic Review, 93(1), 170-192.

Baldwin, R. (2007). "Trade Effects of the Euro: a Comparison of Estimators." Journal of Economic Integration, 22([object Attr]), 780-818.

Barattieri, A., Cacciatore, M., and Ghironi, F. (2018). "Protectionism and the business cycle." Tech. rep., National Bureau of Economic Research.

Barbiero, O., Farhi, E., Gopinath, G., and Itskhoki, O. (2018). "The economics of border adjustment tax." Tech. rep., mimeo, Harvard University and Princeton University.

Bergsten, F. C., and Gagnon, J. E. (2012). "Currency Manipulation, the US Economy, and the Global Economic Order." Policy Briefs PB12-25, Peterson Institute for International Economics.

Berman, N., Martin, P., and Mayer, T. (2012). "How do different exporters react to exchange rate changes?" The Quarterly Journal of Economics, 127(1), 437-492.

Berthou, A. (2008). "An investigation on the effect of real exchange rate movements on OECD bilateral exports." Working Paper Series 0920, European Central Bank.

Berthou, A., and Fontagné, L. (2016). "Variable trade costs, composition effects and the intensive margin of trade." The World Economy, 39(1), 54-71.

Blanchard, O. (2017). "Currency wars, coordination, and capital controls." International Journal of Central Banking.

Boivin, J., Kiley, M. T., and Mishkin, F. S. (2010). "How has the monetary transmission mechanism evolved over time?" Handbook of Monetary Economics, Elsevier.

Bown, C. P., and Crowley, M. A. (2013). "Import protection, business cycles, and exchange rates: Evidence from the Great Recession." Journal of International Economics, 90(1), $50-64$.

Bown, C. P., and Crowley, M. A. (2014). "Emerging economies, trade policy, and macroeconomic shocks." Journal of Development Economics, 111, 261-273.

Boz, E., Gopinath, G., and Plagborg-Møller, M. (2017). "Global Trade and the Dollar." NBER Working Papers 23988, National Bureau of Economic Research, Inc.

Brayton, F., Laubach, T., and Reifschneider, D. L. (2014). "The frb/us model: A tool for macroeconomic policy analysis." Tech. rep., Board of Governors of the Federal Reserve System (US). 
Bussière, M., Gaulier, G., and Steingress, W. (2016). "Global trade flows: Revisiting the exchange rate elasticities." Tech. rep.

Caballero, R. J., Farhi, E., and Gourinchas, P.-O. (2015). "Global Imbalances and Currency Wars at the ZLB." NBER Working Paper 21670, National Bureau of Economic Research, Inc.

Caballero, R. J., Farhi, E., and Gourinchas, P.-O. (2016). "Safe Asset Scarcity and Aggregate Demand." American Economic Review, 106(5), 513-18.

Cline, W. R., and Williamson, J. (2010). "Currency Wars?" Policy Briefs PB10-26, Peterson Institute for International Economics.

Coeuré, B. (2018). "The consequences of protectionism." In Speech at the 29th edition of the workshop "The outlook for the economy and finance".

de Sousa, J. (2012). "The currency union effect on trade is decreasing over time." Economics Letters, 117(3), 917-920.

de Sousa, J., Mayer, T., and Zignago, S. (2012). "Market access in global and regional trade." Regional Science and Urban Economics, 42(6), 1037-1052.

Eaton, J., and Kortum, S. (2002). "Technology, geography, and trade." Econometrica, 70(5), 1741-1779.

Eggertsson, G. B., Mehrotra, N. R., and Summers, L. H. (2016). "Secular Stagnation in the Open Economy." NBER Working Paper 22172, National Bureau of Economic Research, Inc.

Eichengreen, B. (2013). "Currency Wars: perceptions and reality."

Eichengreen, B. (2018). "Trade policy and the macroeconomy." IMF Economic Review, 1-20.

Eichengreen, B., and Irwin, D. A. (2010). "The Slide to Protectionism in the Great Depression: Who Succumbed and Why?" The Journal of Economic History, 70 (04), 871-897.

Evenett, S. J. (2012). "Débâcle: The 11th gta report on protectionism." Centre for Economic Policy Research.

Farhi, E., Gopinath, G., and Itskhoki, O. (2013). "Fiscal devaluations." Review of Economic Studies, 81(2), 725-760.

Feenstra, R. C. (1989). "Symmetric pass-through of tariffs and exchange rates under imperfect competition: An empirical test." Journal of international Economics, 27(1-2), 25-45.

Fitzgerald, D., and Haller, S. (2014). "Exporters and shocks: Dissecting the international elasticity puzzle." Tech. rep., National Bureau of Economic Research.

Fontagné, L., Martin, P., and Orefice, G. (2017). "The international elasticity puzzle is worse than you think." Working Papers 2017-03, CEPII. 
Gaulier, G., and Zignago, S. (2010). "Baci: International trade database at the product-level. the 1994-2007 version." Working Papers 2010-23, CEPII.

Georgiadis, G., and Gräb, J. (2013). "Growth, real exchange rates and trade protectionism since the financial crisis." Working Paper Series 1618, European Central Bank.

Gourinchas, P.-O., and Rey, H. (2016). "Real Interest Rates, Imbalances and the Curse of Regional Safe Asset Providers at the Zero Lower Bound." SSRN Scholarly Paper ID 2840700, Social Science Research Network, Rochester, NY.

Grossman, G. M., and Helpman, E. (1994). "Protection for Sale." American Economic Review, $84(4), 833-50$.

Grossman, G. M., and Helpman, E. (1995). "Trade Wars and Trade Talks." Journal of Political Economy, 103(4), 675-708.

Hale, G., and Hobijn, B. (2016). "Share of imports and commodities in consumption and investment in the united states." In UNCOVERING VALUE ADDED IN TRADE: New Approaches to Analyzing Global Value Chains, 101-112, World Scientific.

Head, K., and Mayer, T. (2014). "Gravity Equations: Workhorse,Toolkit, and Cookbook." Handbook of International Economics, Elsevier.

Head, K., Mayer, T., and Ries, J. (2010). "The erosion of colonial trade linkages after independence." Journal of International Economics, 81(1), 1-14.

Jeanne, O. (2018). "Currency wars, trade wars and the global demand."

Knetter, M. M., and Prusa, T. J. (2003). "Macroeconomic factors and antidumping filings: evidence from four countries." Journal of International Economics, 61 (1), 1-17.

Krugman, P. R. (1979). "Increasing returns, monopolistic competition, and international trade." Journal of international Economics, 9(4), 469-479.

Laeven, L., and Valencia, F. (2012). "Systemic Banking Crises Database; An Update." IMF Working Paper 12/163, International Monetary Fund.

Leigh, D., Lian, W., Poplawski-Ribeiro, M., and Tsyrennikov, V. (2015). "Exchange rates and trade flows: disconnected?" World Economic Outlook, 105-42.

Lindé, J., and Pescatori, A. (2017). "The macroeconomic effects of trade tariffs: Revisiting the lerner symmetry result." IMF Working Paper, 17(151).

Mantega, G. (2010). "Brazil in "currency war"." Financial Times.

Ostry, J. D., Ghosh, A. R., Habermeier, K., Chamon, M., Qureshi, M. S., and Reinhardt, D. B. (2010). "Capital inflows: The role of controls." Staff Position Note SPN/10/04, International Monetary Fund.

Rauch, J. E. (1999). "Networks versus markets in international trade." Journal of international Economics, 48(1), 7-35. 
Rogoff, K., et al. (1995). What remains of purchasing power parity? Boston University, Institute for Economic Development.

Staiger, R. W., and Sykes, A. O. (2010). "currency manipulation'and world trade." World Trade Review, 9(4), 583-627.

Taylor, J. B. (2016). "An international monetary system built on sound policy rules." In Keynote Address International Conference on Macroeconomic Analysis and International Finance, University of Crete, Greece. Crete: University of Crete. 


\section{Appendix A}

Country sample

\begin{tabular}{llll} 
Algeria & Dominican Rep. & Kenya & Portugal \\
Argentina & Egypt & Korea & Russian Federation \\
Australia & El Salvador & Kuwait & Saudi Arabia \\
Austria & Estonia & Kyrgyzstan & Senegal \\
Azerbaijan & Ethiopia & Laos & Sierra Leone \\
Bangladesh & Finland & Latvia & Singapore \\
& France & Lebanon & Slovakia \\
Belgium-Luxembourg & Gabon & Lithuania & Slovenia \\
Belize & Gambia & Madagascar & South Africa \\
Benin & Georgia & Malawi & Spain \\
Bolivia & Germany & Malaysia & Sri Lanka \\
Bosnia and Herzegovina & Ghana & Mali & Sweden \\
Brazil & Greece & Mexico & Switzerland \\
Bulgaria & Guatemala & Moldova & Syria \\
Burundi & Guinea & Mongolia & Tanzania \\
Cameroon & Guinea Bissau & Morocco & Tchad \\
Canada & Honduras & Mozambique & Thailand \\
Central Africa & Hong Kong & Netherlands & Togo \\
Chile & Hungary & New Zealand & Trinidad and Tobago \\
China & India & Nicaragua & Tunisia \\
Colombia & Indonesia & Nigeria & Turkey \\
Costa Rica & Ireland & Norway & Uganda \\
Côte d'Ivoire & Israel & Pakistan & Ukraine \\
Croatia & Italy & Panama & United Kingdom \\
Cyprus & Jamaica & Paraguay & United States \\
Czech Republic & Japan & Peru & Uruguay \\
Dem. Rep. of the Congo & Jordan & Philippines & Venezuela \\
Denmark & Kazakhstan & Poland & Zambia \\
\hline
\end{tabular}




\section{Appendix B: Model linearization}

\section{Trade balance}

$$
\begin{aligned}
B & =X-M \\
d B & =d X-d M \\
\frac{d B}{Y} & =\frac{d X}{Y}-\frac{d M}{Y}
\end{aligned}
$$

Exports in foreign currency are determined by:

$$
X=X_{0} Q^{\epsilon}\left(1+\tau^{*}\right)^{-\zeta \epsilon} Y^{* \gamma^{*}}
$$

For small tariffs, we have $\frac{d\left(1+\tau^{*}\right)}{\left(1+\tau^{*}\right)}=d \ln \left(1+\tau^{*}\right) \simeq d \tau^{*}$, hence:

$$
\frac{d X}{X}=\epsilon \frac{d Q}{Q}-\zeta \epsilon d \tau^{*}+\gamma^{*} \frac{d Y^{*}}{Y^{*}}
$$

Imports in foreign currency are determined by:

$$
M=M_{0} Q^{-\epsilon}(1+\tau)^{-\zeta \epsilon} Y^{\gamma}
$$

For small tariffs, we have $\frac{d(1+\tau)}{(1+\tau)} \simeq d \tau$, hence:

$$
\frac{d M}{M}=-\epsilon \frac{d Q}{Q}-\zeta \epsilon d \tau+\gamma \frac{d Y}{Y}
$$

Since $P=P^{*}=1$, the real exchange rate equals the nominal exchange rate: $Q=E$. Around $B=0$, we have:

$$
\frac{d B}{Y}=\phi\left[2 \epsilon \frac{d E}{E}+\zeta \epsilon\left(d \tau-d \tau^{*}\right)+\gamma\left(\frac{d Y^{*}}{Y^{*}}-\frac{d Y}{Y}\right)\right]+v
$$

where $\gamma=\gamma^{*}, \phi=\frac{X}{Y}=\frac{M}{Y}$, and $v$ an exogenous shock. 
Domestic output With $C=c \frac{P Y}{P_{c}}, I=I_{0}(1+r)^{-\alpha}, P_{c}=P^{1-\eta}\left(P^{*}\right)^{\eta}[E(1+\tau)]^{\pi \eta}$, and $P=P^{*}=1$, we have:

$$
\begin{aligned}
Y & =c[E(1+\tau)]^{-\eta \pi} Y+I_{0}(1+r)^{-\alpha}+E B \\
\frac{d Y}{Y} & =c[E(1+\tau)]^{-\eta \pi} \frac{d Y}{Y}-c \eta \pi E^{-\eta \pi}(1+\tau)^{-\eta \pi}\left(\frac{d E}{E}+\frac{d(1+\tau)}{(1+\tau)}\right) \\
& -\frac{\alpha I_{0}}{Y}(1+r)^{-\alpha} \frac{d(1+r)}{(1+r)}+\frac{B d E}{Y} \\
& +\phi E\left[2 \epsilon \frac{d E}{E}+\zeta \epsilon\left(d \tau-d \tau^{*}\right)+\gamma\left(\frac{d Y^{*}}{Y^{*}}-\frac{d Y}{Y}\right)\right]+v+u,
\end{aligned}
$$

where $\frac{d(1+r)}{(1+r)}=d \ln (1+r) \simeq d r$ if $r \simeq 0$, and $u$ is an exogenous shock.

We linearize around an initial equilibrium where $\tau \simeq 0, E=1, r \simeq 0$ and $B \simeq 0$ :

$$
\begin{aligned}
\frac{d Y}{Y}= & -\frac{\eta \pi c}{1-c+\phi \gamma}\left(\frac{d E}{E}+d \tau\right)-\underbrace{\frac{\alpha I}{Y(1-c+\phi \gamma)}}_{\mu} d r \\
& +\frac{\phi}{1-c+\phi \gamma}\left(2 \epsilon \frac{d E}{E}+\zeta \epsilon\left(d \tau-d \tau^{*}\right)+\gamma \frac{d Y^{*}}{Y^{*}}\right)+\frac{v+u}{1-c+\phi \gamma}
\end{aligned}
$$

After a shock, around the initial equilibrium (where $B \simeq 0, \tau=r=0$ and $E=1$ ) we have $\frac{d B}{X}=b, d \tau=\tau, d r=r$ and $\frac{d E}{E}=d \ln E=d e=e$. With $\frac{d Y}{Y}=y$ and $\frac{d Y^{*}}{Y^{*}}=y^{*}$, we get:

$$
\begin{aligned}
y & =-\frac{\eta \pi c}{1-c+\phi \gamma}(e+\tau)-\mu r+\frac{\phi}{1-c+\phi \gamma}\left(2 \epsilon e+\zeta \epsilon\left(\tau-\tau^{*}\right)+\gamma y^{*}\right)+\frac{v+u}{1-c+\phi \gamma} \\
b & =\phi\left(2 \epsilon e+\zeta \epsilon\left(\tau-\tau^{*}\right)+\gamma\left(y^{*}+y\right)\right)+v \\
e & =\delta\left(r^{*}-r\right)
\end{aligned}
$$

Calibration To calibrate $\mu$, we re-write $y$ so that it only depends on the two policy variables $r$ and $\tau$, on the different parameters and on the two shocks $u$ and $v$ : 


$$
\begin{aligned}
y= & -\left(-\frac{\eta \pi c}{1-c+\phi \gamma}+\mu+2 \epsilon \phi\right) r+\left(\frac{\phi \zeta \epsilon-\eta \pi c}{1-c+\phi \gamma}\right) \tau+\left(\frac{2 \zeta \epsilon-\eta \pi c}{1-c+\phi \gamma}\right) r^{*} \\
& -\frac{\phi \zeta \epsilon}{1-c+\gamma \phi} \tau^{*}+\frac{\phi \gamma}{1-c+\gamma \phi} y^{*}+\frac{v+u}{1-c+\phi \gamma}
\end{aligned}
$$

We thus have the following impact of $\tau$ and $r$ on $y$ and on $b$ :

$$
\begin{aligned}
\frac{\partial y}{\partial r} & =-\left(\mu+\frac{2 \phi \epsilon}{1-c+\phi \gamma}-\frac{\eta \pi c}{1-c+\phi \gamma}\right) \\
\frac{\partial y}{\partial \tau} & =\left(\frac{\phi \zeta \epsilon}{1-c+\phi \gamma}-\frac{\eta \pi c}{1-c+\phi \gamma}\right) \\
\frac{\partial b}{\partial r} & =\left(\frac{\phi 2 \epsilon(1-c-\gamma(1-\phi))}{1-c+\phi \gamma}-\frac{\eta \pi c}{1-c+\phi \gamma}+\gamma \mu\right) \\
\frac{\partial b}{\partial \tau} & =\left(\frac{\phi \zeta \epsilon(1-c-\gamma(1-\phi))+\gamma \eta \pi c}{1-c+\phi \gamma}\right)
\end{aligned}
$$

Then, we calibrate the impact of $r$ on $y$ based on the literature showing the impact of a rate cut on US output. For an overall impact of 0.3 we have the following:

$$
\begin{aligned}
-\left(\mu+\frac{2 \phi \epsilon}{1-c+\phi \gamma}-\frac{\eta \pi c}{1-c+\phi \gamma}\right) & =-0.3 \\
\Leftrightarrow \mu+\frac{0.1}{0.36}-\frac{0.084}{0.36} & =0.3 \\
\Leftrightarrow \mu & =0.26 \approx 0.3
\end{aligned}
$$




\section{Appendix C}

Figure 4: Optimal reaction of tariff depending on $\zeta$

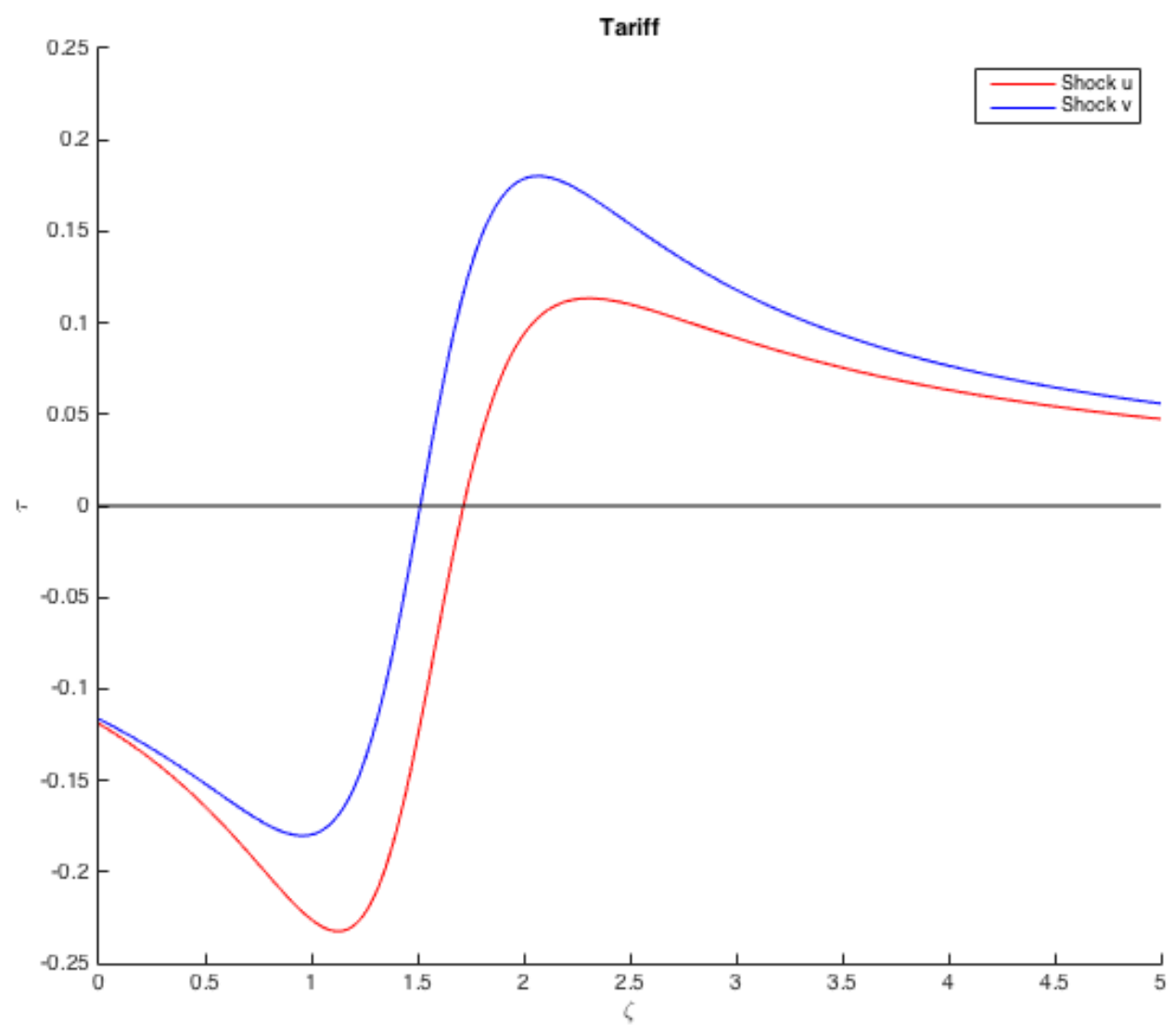

Note: policy responses to a negative demand shock of $u=-1 \%$ in red, and to a negative trade shock $v=-1 \%$ in blue. Source: model simulations. 
Figure 5: Optimal reactions of interest rate depending on $\mu$

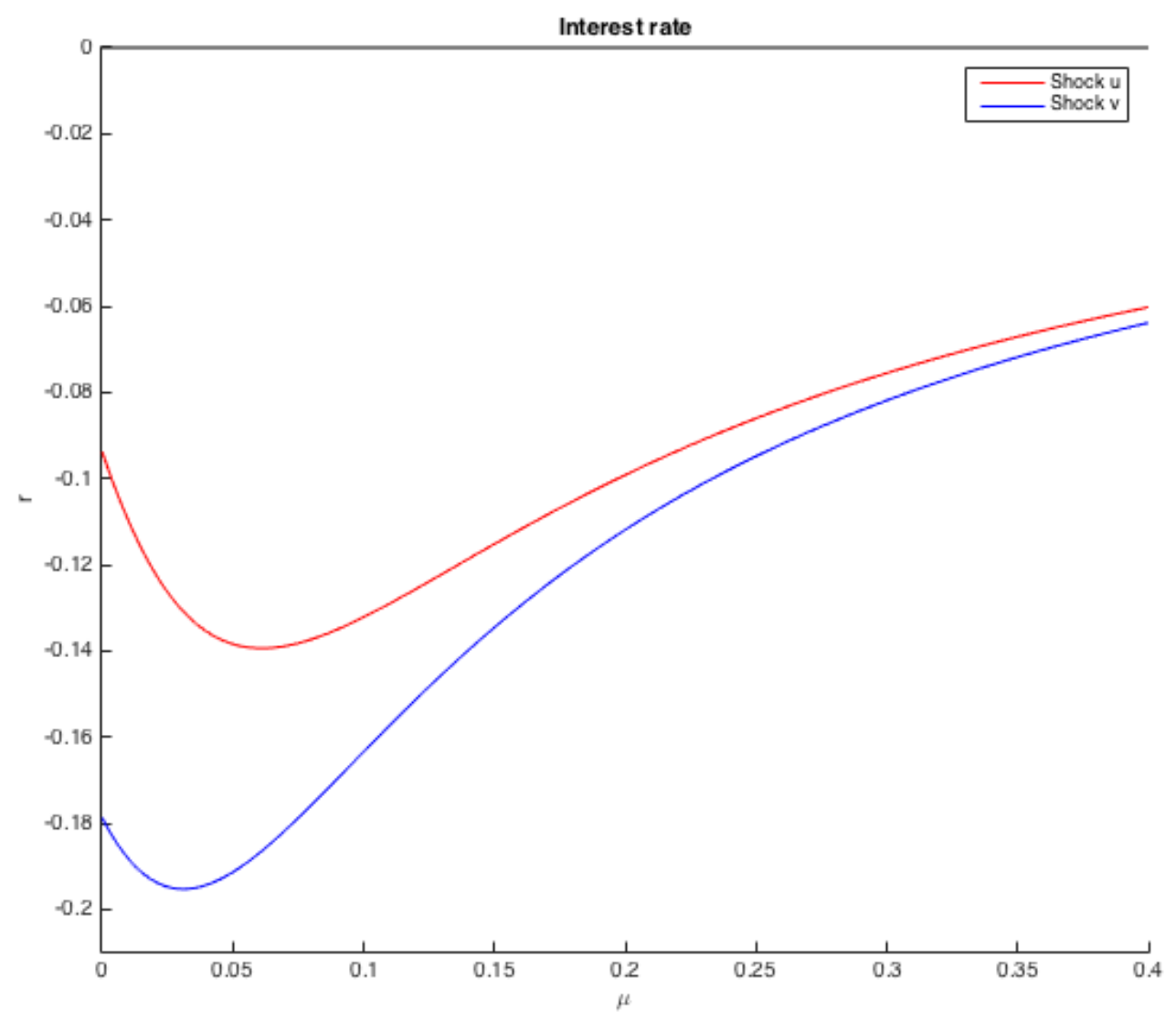

Note: policy responses to a negative demand shock of $u=-1 \%$ in red, and to a negative trade shock $v=-1 \%$ in blue. Source: model simulations. 